Provided for non-commercial research and education use. Not for reproduction, distribution or commercial use.

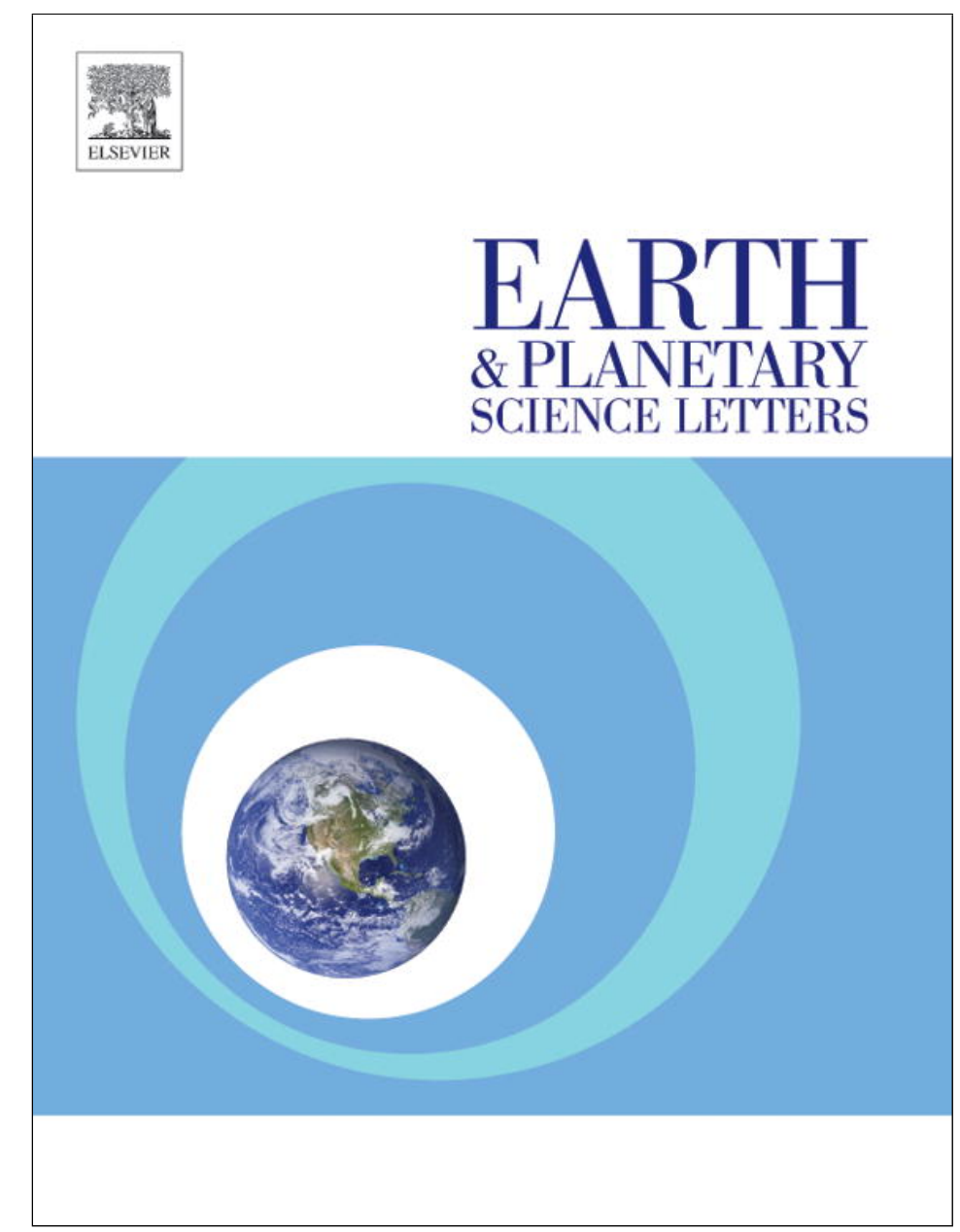

This article appeared in a journal published by Elsevier. The attached copy is furnished to the author for internal non-commercial research and education use, including for instruction at the authors institution and sharing with colleagues.

Other uses, including reproduction and distribution, or selling or licensing copies, or posting to personal, institutional or third party websites are prohibited.

In most cases authors are permitted to post their version of the article (e.g. in Word or Tex form) to their personal website or institutional repository. Authors requiring further information regarding Elsevier's archiving and manuscript policies are encouraged to visit:

http://www.elsevier.com/authorsrights 


\title{
Jadeitite formed during subduction: In situ zircon geochronology constraints from two different tectonic events within the Guatemala Suture Zone
}

\author{
Kennet E. Flores ${ }^{\mathrm{a}, *}$, Uwe C. Martens ${ }^{\mathrm{b}}$, George E. Harlow ${ }^{\mathrm{a}}$, Hannes K. Brueckner ${ }^{\mathrm{c}}$, \\ Norman J. Pearson ${ }^{\mathrm{d}}$ \\ a Department of Earth and Planetary Sciences, American Museum of Natural History, New York, NY 10024-5192, USA \\ ${ }^{\mathrm{b}}$ Department of Geological and Environmental Sciences, Stanford University, Stanford, CA 94305, USA \\ ' Lamont-Doherty Earth Observatory, Columbia University, Palisades, NY 10964, USA \\ ${ }^{\mathrm{d}}$ ARC Centre of Excellence for Core to Crust Fluid Systems (CCFS) and Geochemical Evolution and Metallogeny of Continents (GEMOC) National Key Centre, \\ Department of Earth and Planetary Sciences, Macquarie University, Sydney, NSW 2109, Australia
}

\section{A R T I C L E I N F O}

\section{Article history:}

Received 2 December 2012

Received in revised form

11 April 2013

Accepted 11 April 2013

Editor: T.M. Harrison

\section{Keywords:}

Guatemala jadeitite

zircon

$\mathrm{U}-\mathrm{Pb}$ dating

serpentinite mélange

fluid precipitation

high pressure-lower temperature

metamorphism

\begin{abstract}
A B S T R A T
Jadeitite is a rare rock type associated with high-pressure-low-temperature blocks within serpentinite matrix mélanges. Models of formation involve precipitation from subduction-zone aqueous fluids veining the overlying mantle wedge (P-type), or metasomatism of igneous and/or sedimentary protoliths previously emplaced into the mélange (R-type). Age determinations of mélange lithologies provide constraints on the timing of "peak metamorphism" and subsequent exhumation. The timing of jadeitite formation, particularly in the rich source of the Guatemala Suture Zone (GSZ), is a controversial subject needing further attention.

Over 80 in situ zircon crystals from three jadeitites and two mica-albite rocks from the North Motagua Mélange and one phengite jadeitite from the South Motagua Mélange of the GSZ were studied for age and trace-element determination. Most of these zircons are characterized by low Th/U ratios, depleted chondrite-normalized REE patterns relative to zircons from oceanic gabbros, and contain fluid and mineral inclusions that reflect the primary mineralogy (i.e., jadeite) and context (i.e., crystallization from an aqueous fluid) of the host rock, and thus formed during jadeitite crystallization. The SHRIMP-RG and LAM-ICP-MS U-Pb dates from zircon indicate that jadeitites and mica-albite rocks from the GSZ were formed through vein precipitation at $\sim 98-80$ and $\sim 154-158 \mathrm{Ma}$, respectively. These data show (a) older ages that indicate jadeitite crystallization occurred $\sim 10-30$ Ma before the preserved subduction-zone peak metamorphism (e.g., exhumed eclogite), and (b) a second group of ages slightly younger than, or similar to, exhumation ages given by Ar-Ar dates from micas. Similar relationships occur at other jadeitite occurrences, such as the Syum-Keu ultramafic complex in the Polar Urals (Russia) and the serpentinite mélanges of the Río San Juan complex (Dominican Republic). The data argue for formation of jadeitite within the mantle wedge during active subduction. Thus, jadeitite provides a record of fluid introduction into the mantle wedge during subduction rather than during exhumation.
\end{abstract}

(c) 2013 Elsevier B.V. All rights reserved.

\section{Introduction}

Jadeitite is a rock composed primarily of jadeitic pyroxene that is found in a small number of occurrences associated with highpressure-low-temperature (HP-LT) rocks, such as blueschist, garnetamphibolite and eclogite, within serpentinite-matrix mélange. Recent studies indicate that jadeitite is either a direct vein

\footnotetext{
* Corresponding author. Tel.: +1 212313 7373; fax: +1 2127695339

E-mail addresses: kflores@amnh.org, kennet.flores@gmail.com (K.E. Flores), gharlow@amnh.org (G.E. Harlow), umartens@zoho.com (U.C. Martens), hannes@ldeo.columbia.edu (H.K. Brueckner) norman.pearson@mq.edu.au (N.J. Pearson).
}

precipitate from aqueous fluid ("P type", Tsujimori and Harlow, 2012) or a metasomatic product of extensive to near complete replacement of generally felsic protoliths such as tonalite and/or trondhjemite, but perhaps metagabbros as well ("R-type", Tsujimori and Harlow, 2012). P-type jadeitites are found either as veins, when contact relationships are preserved - which is rarely - or as dismembered remnants in mélanges and their weathering products. These P-type veins are either (a) in contact with antigorite serpentinite bounded by a primary reaction boundary (e.g., Nant Maw 109 mine, Jade Mine Tract, Myanmar; Harlow et al., 2007), (b) in secondary contact with blackwall rinds in serpentinite (e.g., Quebrada El Silencio, South Motagua Mélange, Guatemala), or (c) inside blueschist facies metabasite (e.g., Loma 
Magante Ridge, Río San Juan Complex, Dominican Republic, Schertl et al., 2012). Geochronological constraints are critical for interpreting the timing of jadeitite crystallization relative to the HP-LT metamorphism of other rocks in the mélange. Moreover, such data should help resolve questions about the origin of the two jadeitite-bearing mélanges on either side of the Motagua fault system (MFS) in Guatemala. Our study of zircons expands upon results from Fu et al. (2010) and Yui et al. $(2010,2012)$ on two Guatemalan jadeitites.

\section{Geological setting}

The boundary between the North American and Caribbean plates is defined in Guatemala by a tectonically and geologically complex region classically termed the Motagua Suture Zone (Dengo, 1985). It encompasses three primary parallel, EW trending, left-lateral, strikeslip fault systems, from north to south (a) the Polochic (PolochicChixoy; PFS), (b) the Motagua (San Agustín/Cabañas, Jubuco, Cuyamel; MFS), and (c) the Jocotán (Jocotán-Chamelecón-La Ceiba; JFS-Bonis et al., 1970; Dengo, 1985; Donnelly et al., 1990; see Fig. 1). The Baja Verapaz Shear Zone (BVSZ) is also an important thrust structure, probably related to the above fault systems (Ortega-Gutierrez et al., 2007; Ortega-Obregón et al., 2008). Recent studies show that the presently active plate boundary, with sinistral transcurrent motion, is restricted to the PFS and MFS, which display active structural geometry, recent displacements and well documented paleo-seismic events (Authemayou et al., 2011, 2012; Brocard et al., 2011).

This plate boundary has accommodated at least $\sim 1100 \mathrm{~km}$ of left-lateral strike-slip motion over the Cenozoic, since the opening of the Cayman oceanic spreading center in the Caribbean Sea (Leroy et al., 2000; Pindell et al., 2005; Rosencrantz et al., 1988). Most of this displacement was accommodated by the MFS, which brings into contact two geologically distinctive continental blocks: the Maya block, the southernmost extent of the North America plate, and the Chortís block, a continental fragment tectonically conjoined to allochthonous Mesozoic oceanic crust from the Caribbean plate (Dengo, 1969, 1985; Donnelly et al., 1990; Keppie and Morán Zenteno, 2005; Ortega-Gutierrez et al., 2007; Sapper, 1905). The contact zone contains many ultramafic and mafic bodies and associated oceanic sedimentary sequences as well as HP-LT rocks originally interpreted as pieces of a dismembered Cretaceous ophiolite. These lithologies record a major oceanic suture between these blocks (Dengo, 1969; Donnelly et al., 1990 and references therein). However, recent studies of the oceanic and continental metamorphic rocks in this area have added complexity to this interpretation. They suggest that the Motagua Suture Zone results from at least two different major tectonic events during the Early and Late Cretaceous. The main arguments for this new interpretation are the occurrence of at least three different HP-LT signatures, oceanic rocks of very diverse origin, and the distinctly different crustal blocks north and south of the MFS (e.g., Brueckner et al., 2009; Chiari et al., 2006; Geldmacher et al., 2007; Harlow et al., 2004; Martens et al., 2012; Ortega-Gutierrez et al., 2007; Ortega-Obregón et al., 2008; Ratschbacher et al., 2009; Solari et al., 2009, 2011).

The evolving geodynamic interpretation suggests the Motagua Suture Zone should be renamed the Guatemala Suture Zone (Brueckner et al., 2009) or the Guatemala Suture Complex (Martens et al., 2012). Here we use Guatemala Suture Zone (GSZ), which has precedence in redefining the geodynamics of this area and does not conflict with the name of a major fault system, the MFS.

\subsection{Origin of the GSZ HP-LT rocks}

Until recently, the tectonic origin of the HP-LT rocks north and south of the MFS was assigned to a single tectonic (collisional)

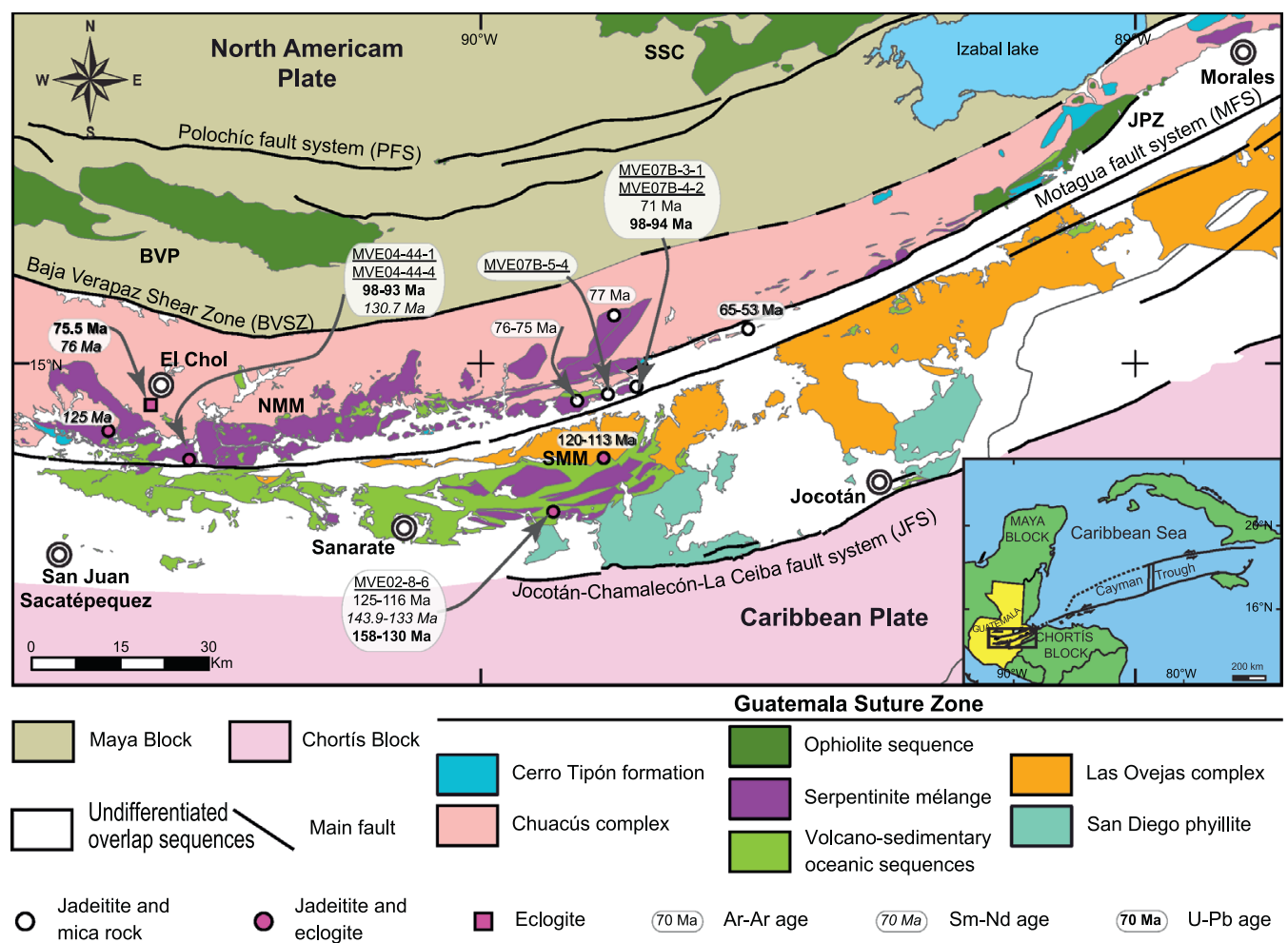

Fig. 1. A simplified tectonic map of central Guatemala Suture Zone (GSZ) showing distribution of key units such as: serpentinite mélanges, ophiolites and oceanic crust sequences, as well as, the location of geochronological results from our collaborative research. Sample numbers from this study are underlined. The ages in regular font refer to Ar-Ar data (after Harlow et al., 2004), bold font to U-Pb (after Fu et al., 2010; Yui et al., 2010, 2012; this paper) and italic font to Sm-Nd (after Brueckner et al., 2009; Martens et al., 2012). Abbreviations for the main units: Sierra de Santa Cruz ophiolite (SSC), Baja Verapaz ophiolite (BVP), Juan de Paz ophiolite (JPZ), North Motagua Mélange (NMM), and South Motagua Mélange (SMM). 
event in the Late Cretaceous, although all studies note the strong lithotectonic dichotomy across the MFS (Dengo, 1969; Donnelly et al., 1990). The north Motagua mélange (NMM), north of the MFS, is a serpentinite mélange that hosts garnet amphibolite, omphacite-taramite metabasite, jadeitite, albitite, and, more recently reported, altered clinozoisite-amphibole-eclogite in its western reaches (Brueckner et al., 2009; Harlow, 1994; Tsujimori et al., 2004). These rocks span a wide range of conditions, from greenschist-blueschist at lower $P\left(200-400{ }^{\circ} \mathrm{C}\right.$ at $\left.\leq 1 \mathrm{GPa}\right)$ to low-tomoderate $T$ eclogite facies of $500-650{ }^{\circ} \mathrm{C}$ at $\sim 1.5-2.3 \mathrm{GPa}$ (Harlow et al., 2008; Tsujimori et al., 2004). In contrast, assemblages in the South Motagua Mélange (SMM; south of the MFS) include lawsonite eclogite, blueschist, and jadeitite that record peak $P-T$ conditions among the coldest and wettest deep-subduction trajectories on Earth, to $\sim 2.6 \mathrm{GPa}$ and only $\sim 470{ }^{\circ} \mathrm{C}$ (Tsujimori et al., 2006a, 2006b).

Based on contrasting phengite ${ }^{40} \mathrm{Ar} /{ }^{39} \mathrm{Ar}$ ages from HP-LT rocks across the MFS, Harlow et al. (2004) proposed that the GSZ hosts at least two HP-LT serpentinite mélange belts of different ages and origins. The older SMM yields ${ }^{40} \mathrm{Ar} /{ }^{39} \mathrm{Ar}$ ages of $125-113 \mathrm{Ma}$ and was probably formed during an Aptian subduction-collision between the Chortís block and the active margin of southern Mexico along the Pacific Ocean margin. Whereas, the younger NMM yields ${ }^{40} \mathrm{Ar} /{ }^{39} \mathrm{Ar}$ ages of $77-53 \mathrm{Ma}$ interpreted as forming during a Maastrichtian collision between the Chortís and Maya blocks. However, this interpretation required modification based on Sm-Nd mineral isochrons from eclogites both north and south of the MFS, which yielded nearly overlapping mean ages of 130.7$125 \mathrm{Ma}$ and 143.9-132.1 Ma, respectively (Brueckner et al., 2009). The combined age data suggest an initial HP-LT event at $\sim 130 \mathrm{Ma}$ for both sides of the MFS and a subsequent second event at $\sim 75$ Ma only recorded north of the MFS. In addition, high-grade schist and gneiss of the Chuacús complex, the southern edge of the continental Maya block, contain retrograded eclogites indicating a third HP-LT belt (Ortega-Gutierrez et al., 2004). The Chuacús eclogites yielded Sm-Nd mineral and U-Pb zircon ages of $\sim 76 \mathrm{Ma}$ and PT conditions of $\sim 700{ }^{\circ} \mathrm{C}$ at $\sim 2.1-2.4 \mathrm{GPa}$ (Martens et al., 2012). This age clusters perfectly with the second event only recorded in the NMM. Where do the jadeitites fit in this complicated chronology? This is the driving question for this study.

\subsection{Jadeitites and related rock from the GSZ}

Jadeitite north of the MFS was first described in detail by Harlow (1994) and consists primarily of granoblastic jadeitic pyroxene with lesser amounts of paragonite $(\mathrm{Pg})$, phengite $(\mathrm{Ph})$, omphacite (Omp), albite (Ab), minor zircon (Zrn), apatite and graphite. Alteration along grain boundaries consists of $\mathrm{Ab}$, analcime (Anl), taramitic amphibole, zoisite/clinozoisite (Zo/Czo), nepheline (Ne), and preiswerkite (a mica: $\operatorname{NaMg}_{2} \mathrm{Al}_{3} \mathrm{Si}_{2} \mathrm{O}_{10}(\mathrm{OH})_{2}$ ). Recently, the known distribution of jadeitite north of the MFS has been dramatically enlarged, but with little change in their mineral assemblage except for a sole occurrence of pumpellyite jadeitite near Saltán, at the west end of the $200 \mathrm{~km}$ long belt (Harlow et al., 2011). Jadeitite also occurs south of the MFS in three distinct serpentinite bands near the towns of Carrizal Grande, La Ceiba and La Ensenada. Jadeitite from the first two locations generally contains jadeite (Jd), Omp, quartz (Qtz), titanite (Ttn), $\pm \mathrm{Ab}$, sometimes with cymrite, vesuvianite, and pectolite. At La Ensenada the rock is a pumpellyite jadeitite with $\mathrm{Ab}$ and grossular plus rare $\mathrm{Ph}$, Ttn, apatite, chlorite, Zrn and celsian (Harlow et al., 2011).

Table 1

Location and rock description of mineral assemblages of the four studied jadeitites and two mica-albite rock samples, with details about zircon.

\begin{tabular}{|c|c|c|c|c|c|}
\hline $\begin{array}{l}\text { Sample and } \\
\text { lithology }\end{array}$ & Location & $\begin{array}{l}\text { Latitude } \\
\text { and } \\
\text { longitude }\end{array}$ & $\begin{array}{l}\text { Assemblage } \\
\text { primary/secondary }\end{array}$ & $\begin{array}{l}\text { Zircon host/ } \\
\text { inclusions }\end{array}$ & CL image texture \\
\hline \multicolumn{6}{|c|}{ North Motagua Mélange } \\
\hline $\begin{array}{l}\text { MVE04-44-1 } \\
\text { Jadeitite }\end{array}$ & $\begin{array}{l}\text { Quebrada Los } \\
\text { Pescaditos, Rincón } \\
\text { Grande }\end{array}$ & $\begin{array}{l}14^{\circ} 51^{\prime} \\
7.620^{\prime \prime} \mathrm{N} \\
90^{\circ} 26^{\prime} \\
37.920^{\prime \prime} \mathrm{W}\end{array}$ & $\begin{array}{l}\text { P: Jd, Omp, Pg/Ph, Zrn } \\
\text { S: Ab, Anl, Bnl, Prs, Ne }\end{array}$ & $\begin{array}{l}\text { Host: Jd } \\
\text { Inclus.: Jd, } \\
\text { Fluid }\end{array}$ & $\begin{array}{l}\text { Generally dark uniform interiors with thin bright overgrowths; some } \\
\text { with dark patchy zoning }\end{array}$ \\
\hline $\begin{array}{l}\text { MVE04-44-4 } \\
\text { Jadeitite }\end{array}$ & $\begin{array}{l}\text { Quebrada Los } \\
\text { Pescaditos, Rincón } \\
\text { Grande }\end{array}$ & $\begin{array}{l}14^{\circ} 51^{\prime} \\
7.620^{\prime \prime} \mathrm{N} \\
90^{\circ} 26^{\prime} \\
37.920^{\prime \prime} \mathrm{W}\end{array}$ & $\begin{array}{l}\text { P: Jd, Omp, Pg/Ph, Ttn, } \\
\text { Zrn } \\
\text { S: Ab, Anl, Bnl, Prs, Ne }\end{array}$ & $\begin{array}{l}\text { Host: Jd } \\
\text { Inclus.: Jd, } \\
\text { Fluid }\end{array}$ & $\begin{array}{l}\text { Generally dark uniform interiors with thin bright overgrowths; some } \\
\text { with dark patchy zoning }\end{array}$ \\
\hline $\begin{array}{l}\text { MVE07B-3-1 } \\
\text { Jadeitite }\end{array}$ & $\begin{array}{l}\text { Cerro Colorado, } \\
\text { La Palmilla }\end{array}$ & $\begin{array}{l}14^{\circ} 57^{\prime} \\
53.712^{\prime \prime} \mathrm{N} \\
89^{\circ} 45^{\prime} \\
30.636^{\prime \prime} \mathrm{W}\end{array}$ & $\begin{array}{l}\text { P: Jd, Omp, Pg/Ph/Phl, } \\
\text { Ttn, Zrn } \\
\text { S: Ab, Czo, Brt, Hm }\end{array}$ & $\begin{array}{l}\text { Host: Omp/ } \\
\text { Ab } \\
\text { Inclus.: } \\
\text { Omp, } \\
\text { Fluid }\end{array}$ & $\begin{array}{l}\text { Some uniform dark interiors with thin rhythmic overgrowths; others } \\
\text { with patchy or complex zoning throughout }\end{array}$ \\
\hline $\begin{array}{l}\text { MVE07B-4-2 } \\
\text { Mica-albite } \\
\text { rock }\end{array}$ & $\begin{array}{l}\text { Cerro Colorado, } \\
\text { La Palmilla }\end{array}$ & $\begin{array}{l}14^{\circ} 57^{\prime} \\
55.980^{\prime \prime} \mathrm{N} \\
89^{\circ} 45^{\prime} \\
29.700^{\prime \prime} \mathrm{W}\end{array}$ & $\begin{array}{l}\text { P: Ph, Ab, Zoi, Zrn } \\
\text { S: Chl, Tlc }\end{array}$ & $\begin{array}{l}\text { Host: Ph } \\
\text { Inclus.: } \\
\text { Zoi, Qtz, } \\
\text { Fluid }\end{array}$ & $\begin{array}{l}\text { Uniform dark interiors (or } 2-3 \text { zones) with rhythmic overgrowths; rarer } \\
\text { patchy zoning }\end{array}$ \\
\hline $\begin{array}{l}\text { MVE07B-5-4 } \\
\text { Mica-albite } \\
\text { rock }\end{array}$ & $\begin{array}{l}\text { Cerro Gallinero, } \\
\text { Huijó }\end{array}$ & $\begin{array}{l}14^{\circ} 57^{\prime} \\
2.700^{\prime \prime} \mathrm{N} \\
89^{\circ} 48^{\prime} \\
5.580^{\prime \prime} \mathrm{W}\end{array}$ & $\begin{array}{l}\text { P: Ph, Ab, Zoi, Zrn } \\
\text { S: Chl, Tlc }\end{array}$ & $\begin{array}{l}\text { Host: Ph } \\
\text { Inclus.: } \\
\text { Zoi, Qtz, } \\
\text { Fluid }\end{array}$ & $\begin{array}{l}\text { Uniform dark interiors (or } 2-3 \text { zones) with rhythmic overgrowths; rarer } \\
\text { patchy zoning }\end{array}$ \\
\hline \multicolumn{6}{|c|}{ South Motagua Mélange } \\
\hline $\begin{array}{l}\text { MVE02-8-6 } \\
\text { Phengite } \\
\text { Jadeitite }\end{array}$ & $\begin{array}{l}\text { Quebrada El Silencio, } \\
\text { Carrizal Grande }\end{array}$ & $\begin{array}{l}14^{\circ} 46^{\prime} \\
42.900^{\prime \prime} \mathrm{N} \\
89^{\circ} 53^{\prime} \\
15.720^{\prime \prime} \mathrm{W}\end{array}$ & $\begin{array}{l}\text { Pri: Jd (Ab), Omp, Ph, Ttn, } \\
\text { Rt, Zrn, Qtz, Mon, Aln } \\
\text { Sec: Ab }\end{array}$ & $\begin{array}{l}\text { Host: Jd, Ph } \\
\text { Inclus.: } \\
\text { Fluid }\end{array}$ & $\begin{array}{l}\text { Some uniform dark interiors, some all rhythmic zoning; a few with } \\
\text { patchy or complex zoning; a few with change in brightness along cracks }\end{array}$ \\
\hline
\end{tabular}

Mineral abbreviations: Ab—albite, Aln—allanite, Amp-amphibole, Anl—analcime, Bnl—banalsite, Brt—barite, Chl—chlorite, Czo—clinozoisite, Fsp—feldspar, Gln— glaucophane, Grt—garnet, Hm—hematite, Jd—jadeite, Ky—kyanite, Mca—mica, Mon—monazite, Ms—Muscovite, Ne—nepheline, Omp—omphacite, Pg—paragonite, Ph— phengitic muscovite, Phl—phlogopite, Prs—preiswerkite, Qtz-quartz, Rt—rutile, Tlc—talc, Ttn—titanite, Zoi—zoisite, Zrn—zircon. 
A SMM phengite jadeitite from near Carrizal Grande yielded a U-Pb zircon LA-ICP-MS date of $153.7 \pm 3.5 \mathrm{Ma}$ (Fu et al., 2010). The zircons were interpreted as a mix of hydrothermal and inherited material, based primarily on the U-Pb zircon age being older than the $\mathrm{Ar}-\mathrm{Ar}$ and $\mathrm{Sm}-\mathrm{Nd}$ ages from jadeitite and eclogite reported by Harlow et al. (2004) and Brueckner et al. (2009). Other reasons for their interpretation are discussed below.

A NMM jadeitite from Cerro Colorado, near La Palmilla, yielded a U-Pb zircon SHRIMP-RG age of $95.1 \pm 3.6$ (Yui et al., 2010), which was later constrained to a tighter age of $98.3 \pm 1.6$ (Yui et al., 2012). The zircons were interpreted as primary, i.e., crystallized with jadeite as a metasomatic/solution-precipitate because of their (a) low Th/U ratios, (b) small Ce anomalies, (c) low ${ }^{176} \mathrm{Lu} /{ }^{177} \mathrm{Hf}$ ratios, and (d) the occurrence of other precipitated minerals (Ab, Anl, Pg, Qtz, Jd and Omp) and two-phase fluid inclusions within the zircons. Previous dating from jadeitite and mica-albite rocks in the immediate area gave much younger $\mathrm{Ar}-\mathrm{Ar}$ dates from 77 to $53 \mathrm{Ma}$ (Harlow et al., 2004).

\section{Sample descriptions}

Samples used in this study include three jadeitites and two mica-albite rocks from the NMM (Harlow, 1994) and one phengite jadeitite from the SMM (Fig. 1 and Table 1). No zircon dates from jadeitite north of the MFS existed when this work commenced in early 2010. Thus, we selected jadeitite samples from the western and central NMM and included mica-albite rocks, because it was not clear whether they represented just a stage in vein crystallization or perhaps record the exhumation processes, and thus are potentially younger than the jadeitites.

Jadeitite samples MVE04-44-1 (Fig. 2a) and MVE04-44-4 are from the western end of the NMM (Fig. 1 and Table 1). They are white-green granoblastic jadeitite composed of Jd, Omp, $\mathrm{Pg} / \mathrm{Ph}$ and Zrn. Both samples have considerable secondary alteration along grain boundaries and fractures filled with $\mathrm{Ab}, \mathrm{Anl}$, and some $\mathrm{Ne}, \mathrm{Pg}$ alteration to preiswerkite, plus $\mathrm{Ba}$ enrichment as banalsite (a feldspar: $\mathrm{BaNa}_{2} \mathrm{Al}_{4} \mathrm{Si}_{4} \mathrm{O}_{16}$ ) in veins. Zircons from both samples occur within jadeite crystals and contain Jd and fluid inclusions. These samples are from a stream bed in the mélange that also contained blocks of eclogite (Sm-Nd data in Brueckner et al. (2009)), and serpentinite.

Three samples are from the central part of the NMM (Fig. 1 and Table 1). MVE07B-3-1 (Fig. 2b) is a light green granoblastic jadeitite consisting of Jd, Omp, $\mathrm{Pg} / \mathrm{Ph} /$ phlogopite and accessory Ttn and Zrn. Much of the jadeite is replaced by Ab but abundant Omp is unaffected. Zircons are contained within omphacite and albite and contain Omp and fluid inclusions. Mica-albite rock MVE07B4-2 (Fig. 2c) is a gray-tan, coarse-grained ( $\leq 5 \mathrm{~mm}$ ) phengitic muscovite rock with minor Ab, Zo and Zrn. Secondary talc and chlorite occur along grain boundaries. Both samples were collected from an area very close to the source of sample GJ of Yui et al. a

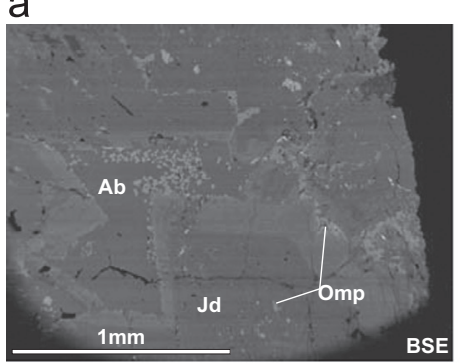

d

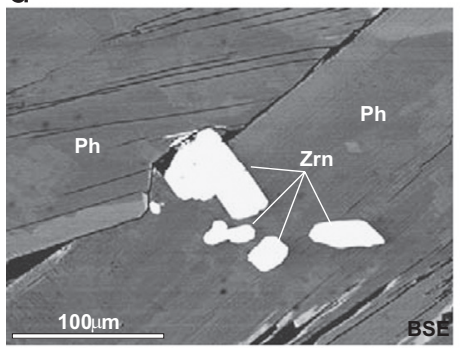

9

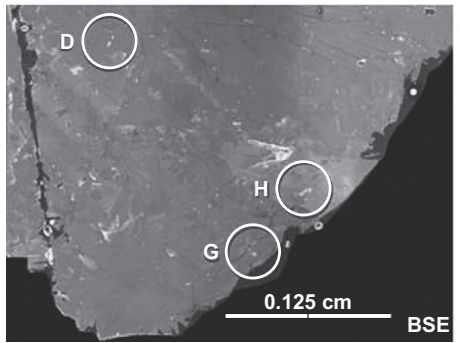

b

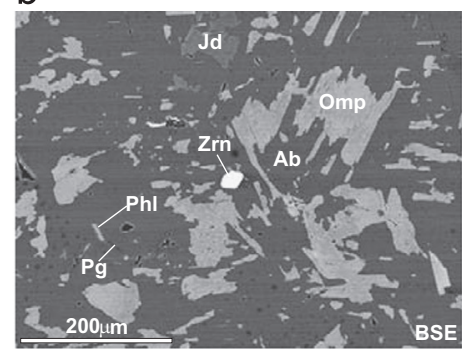

e

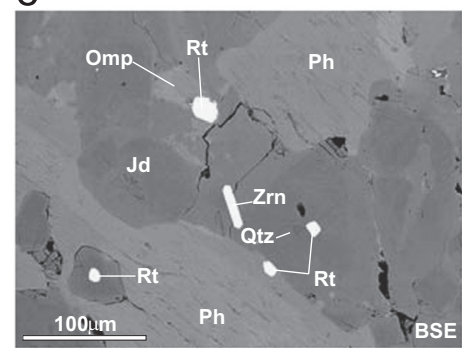

$\mathrm{h}$

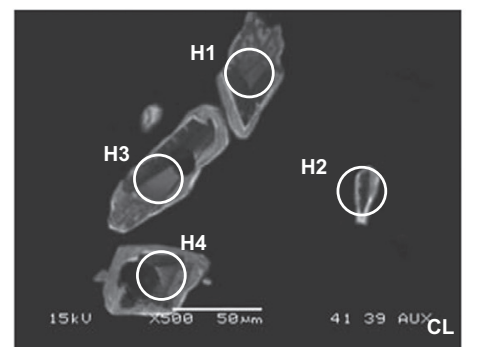

C

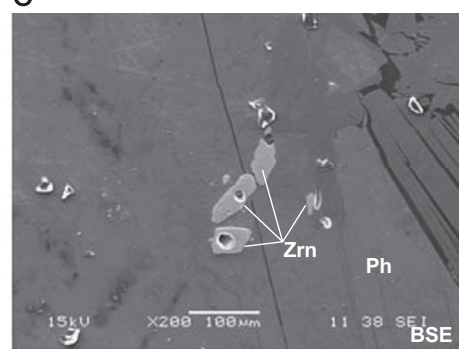

f

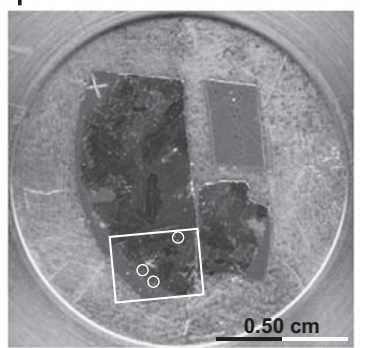

i

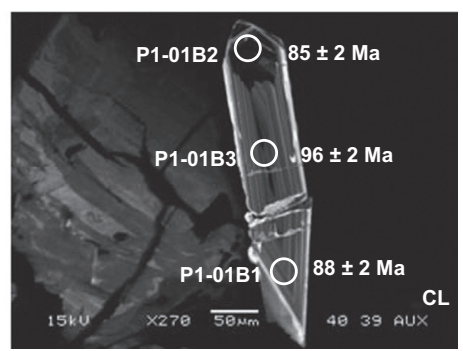

Fig. 2. Photomicrographs and SEM/BSE/CL images of representative jadeitites and mica-albite rock samples showing diverse mineral assemblages and rock textures, as well as precipitated zircons. (a) Jadeitite MVE04-44-1; (b) jadeitite MVE07B-3-1; (c) mica-albite rock MVE07B-4-2; (d) mica-albite rock MVE07B-5-4; (e) phengite-jadeitite MVE02-8-6; (f) examples of thin and polished section fragments on SHRIMP mount T02; (g) polished section SE map with circles indicating the areas with dateable single zircons or zircon clusters; (h) and (i) CL images of zircons from sample MVE07B-4-2 and jadeite MVE04-44-4, were circles show the beam size. U-Pb SHRIMP dating on the rare large P1-01 zircon show contrasting ages between core and rims. 
(2010, 2012). A second sample of mica-albite rock MVE07B-5-4 (Fig. 2d) similar to MVE07B-4-2 was collected several kilometers further west. Zircons from both mica-albite samples are hosted in phengite grains and contain Zo, Qtz and fluid inclusions.

Finally, sample MVE02-8-6 (Fig. 2e), a phengite jadeitite block from near Carrizal Grande (Fig. 1 and Table 1), is the only sample from the SMM and was also studied by Fu et al. (2010). In contrast to the NMM counterparts, the jadeite in the SMM sample exhibits a more prismatic rather than granoblastic texture, with grains $<2 \mathrm{~mm}$ and tabular $\mathrm{Ph}$ grains $\geq 5 \mathrm{~mm}$. Jd grains contain small inclusions of Omp, Ph, Ttn, rutile, Zrn, Qtz, monazite and allanite. Zircon grains contain fluid inclusions.

\section{Analytical methods}

All studied zircons were analyzed in situ using fragments of polished sections or thin sections (Fig. 2f). Zircon crystals were located by optical, secondary electron (SE; Fig. 2g), or back-scattered electron (BSE) imaging and subsequently examined by cathodoluminescence (CL; Fig. 2h and i) imaging with a Hitachi S-4700 FieldEmission Scanning Electron Microscope (SEM) equipped with a Gatan MonoCL3 system in the Microscopy and Imaging Facility at American Museum of Natural History (AMNH). Additional detailed SEM mapping of selected fragments and BSE, CL and SE images of zircons (Appendix 1) were carried out using a JEOL JSM 5600 SEM equipped with a Hamamatsu photomultiplier tube at the at the Stanford USGS Micro Analysis Center (SUMAC). The zirconrich fragments were mounted in 1 in. disks of epoxy and polished (e. g., Fig. 2f). Then, the mounts were coated with high-purity Au. Most of the in situ zircon $\mathrm{U}-\mathrm{Pb}$ data and rare earth element (REE) abundances were determined using the SUMAC SHRIMP-RG (sensitive high resolution ion micro-probe reverse geometry) facility. The reduced ${ }^{206} \mathrm{~Pb} /{ }^{238} \mathrm{U}$ values were normalized to zircon standard R33 (419 Ma age, Black et al., 2004) during separate analytical sessions using $\sim 5 \mathrm{nA} \mathrm{O}_{2}$-primary beam focused to $\sim 25 \mu \mathrm{m}$, and mass resolution was set to $\sim 7000-8000$ at $10 \%$ peak height. Data were reduced using programs Squid and Isoplot (Ludwig, 2001, 2003). U, Th, and trace element concentrations were calibrated against the well-characterized homogeneous zircon standard MAD 4.6 (Madagascar green zircon, $4196 \mathrm{ppm} \mathrm{U}$ ). For trace element analyses, we selected one isotope representing each element based on its relative abundance, trying to avoid significant interferences at the particular mass, similar to the procedure in Mattinson et al. (2006). Peaks at ${ }^{89} \mathrm{Y},{ }^{139} \mathrm{La},{ }^{140} \mathrm{Ce},{ }^{146} \mathrm{Nd},{ }^{148} \mathrm{Sm},{ }^{153} \mathrm{Eu},{ }^{157} \mathrm{Gd},{ }^{163} \mathrm{Dy},{ }^{166} \mathrm{Er}^{16} \mathrm{O},{ }^{172} \mathrm{Yb}^{16} \mathrm{O}$, ${ }^{180} \mathrm{Hf}^{16} \mathrm{O}$ were counted for $2 \mathrm{~s}$ and normalized to ${ }^{96} \mathrm{Zr}$. Additionally, 16 in situ U-Pb LAM-ICP-MS (laser ablation microprobe-inductively coupled plasma-mass spectrometry) analyses on zircon grains from two polished sections (MVE07B-4-2 and MVE07B-5-4) were performed at the GEMOC ARC National Key Centre at Macquarie University (Sydney, Australia) using a HP 4500 series 300 inductively coupled plasma quadrupole mass spectrometer attached to a New Wave $213 \mathrm{~nm}$ Nd:YAG laser using He carrier gas. Analytical procedures are described in detail by Belousova et al. (2001) and Jackson et al. (2004). The GEMOC GJ-1 zircon (age 609 Ma) was used as the primary standard, and zircon standards 91500 (Wiedenbeck et al., 1995) and Mud Tank (Black and Gulson, 1978) and NIST-610 standard glass were analyzed with each sample run as controls on precision and accuracy. Individual $\mathrm{U}-\mathrm{Pb}$ ages were calculated from the raw signal data using the software package GLITTER (Griffin et al., 2008). U and Th concentrations were calculated using the GEMOC GJ-1 zircon ( $\mathrm{U}=230 \mathrm{ppm}$ and $\mathrm{Th}=18 \mathrm{ppm}$ ) as an external standard. Concentrations were calculated by comparing signal intensity and concentrations of the standards and extrapolating their ratios to the signal intensity from the samples.
Because all analyses were conducted on in situ zircons, which sometimes were smaller than the beam size, measured isotopic ratios and concentrations represent the average of the ablated material. In most cases, even when portions of other mineral species were hit, the radiogenic component can be assumed to be that of the zircon whereas the common lead component is chiefly controlled by the enclosing or adjacent minerals. Total elemental concentrations, including the REE, are expected to be only accurate when the spot was fully contained within a zircon grain.

\section{Results}

The $\mathrm{U}-\mathrm{Pb}$ zircon dates and trace-element concentrations are compiled in Appendices 2, 3 and 4, respectively. The calculated ages and details of the data regressions are explained in Table 2, Figs. 3 and 4. In contrast to what was expected, measured elemental concentrations were independent of zircon size. Based on their chemistry (rather than age or source), the analyzed samples can be divided in two types. A first type represented by two jadeitites from the western NMM (MVE04-44-1 and MVE0444-4) and the SMM Ph-jadeitite (MVE02-8-6) is characterized by low common lead content $\left(\mathrm{Pb}_{\mathrm{c}}<\sim 5 \%\right)$, high $\mathrm{U}$ and $\mathrm{Y}$ concentrations, and chondrite-normalized REE patterns comparable to those of zircons from MORB gabbro and eclogite veins (Fig. 5). Zircons from this type category yielded well-constrained $\mathrm{U}-\mathrm{Pb}$ ages (Fig. 3). The second type is represented by jadeitite and micaalbite rocks from the central NMM (MVE07B-3-1, MVE07B-4-1 and MVE07B-5-4), which yields analyses with high $\mathrm{Pb}_{c}$ content ( $>\sim 5 \%$ ), low $U$ and $Y$ concentrations, and chondrite-normalized REE patterns that show depletion relative to zircons from MORB gabbro and eclogite veins. The ages among this type are generally poorly constrained and are shown in Fig. 4. The high $\mathrm{Pb}_{\mathrm{c}}$ content and low elemental concentrations found in this type probably indicates a different fluid source or origin for all the vein crystallization products, including their zircons, from the central NMM or zircon crystallization affected by a phases less competitive for $\mathrm{Y}$ and $\mathrm{U}$ than in type 1 samples.

\subsection{Western North Motagua Mélange jadeitites}

MVE04-44-1: The 22 dated zircons from this jadeitite can be grouped in two size ranges of $10-20 \mu \mathrm{m}$ and $25-50 \mu \mathrm{m}$. Most zircons are euhedral to subhedral crystals (Appendix 1 and Fig. A1.1). $\mathrm{CL}$ images show patchy zoning in most grains; however, some unzoned and concentric growths occur (4 of 22 grains). Uranium and Yttrium contents range from 201 to $6957 \mathrm{ppm}$ and from 158 to $2094 \mathrm{ppm}$, respectively. The $\mathrm{Th} / \mathrm{U}$ ratios range from 0.01 to 0.07 . Individual U-Pb ages range from 69 to $105 \mathrm{Ma}$ and define a lower intercept age of $98.2 \pm 3.9 \mathrm{Ma}$ (Fig. 3a). However, ages from this sample may define two groups: a well-constrained concordant older group (17 of 22 grains) yielding similar lower intercepts and model ages of 97.7 and $95 \mathrm{Ma}$, respectively; a second group of zircons with scattered discordant younger ages has higher $\mathrm{Pb}_{\mathrm{c}}$ and gave intercept and model ages of 82.6 and $71.9 \mathrm{Ma}$, respectively (Fig. 3a and b). The chondrite-normalized REE patterns show depleted LREE, enriched HREE, negative Eu anomalies (13 of 22), and some positive $\mathrm{Ce}$ anomalies ( 9 of 22). The latter are similar to zircon patterns from an eclogite facies vein (Qtz-Omp-Ph) in the Sesia-Lanzo Zone of the Alps (Rubatto, 2002; Fig. 5a).

MVE04-44-4: The 10 zircons dated in this sample are 25 to $175 \mu \mathrm{m}$ across. They are euhedral to subhedral and exposed as long to crosscut prisms. CL images show concentric, sometimes rhythmic, growth zonation (e.g., Appendix 1 and Fig. A1.2e), but approximately half of the dated zircons show patchy zoning. The $U$ and $Y$ content and Th/U ratio ranges are 413-3574 ppm, 204-3684 ppm and 0.03-0.15, 
Table 2

Summary of zircon U-Pb ages and Th/U ratios on jadeitites and mica-albite rocks from the GSZ mélanges. Previous published data (italic) from Fu et al. (2010) and Yui et al. $(2010,2012)$

\begin{tabular}{|c|c|c|c|c|c|c|c|c|c|c|c|}
\hline \multirow[t]{3}{*}{ Sample } & \multicolumn{5}{|c|}{ Tera-Wasserburg concordia ages } & \multicolumn{4}{|c|}{ Tera-Wasserburg model ages } & \multirow[t]{3}{*}{${ }^{232} \mathrm{Th} /{ }^{238} \mathrm{U}$ ratio } & \multirow[t]{3}{*}{ Method } \\
\hline & \multicolumn{5}{|c|}{ (Ma) } & \multicolumn{4}{|l|}{ (Ma) } & & \\
\hline & & cepts & \pm Error & MSWD & $n^{u} / n^{t}$ & Mean & \pm Error & MSWD & $n^{u} / n^{t}$ & & \\
\hline \multicolumn{12}{|l|}{ West North Motagua Mélange } \\
\hline \multirow[t]{9}{*}{ Jadeitite (MVE04-44-1) } & $l$ & 98.2 & 3.9 & $1.90^{\mathrm{a}}$ & $22 / 22$ & 88.2 & 5.2 & $2.80^{\mathrm{c}}$ & $22 / 22$ & $0.01-0.07$ & SHRIMP-RG \\
\hline & $u$ & - & - & & & & & & & & \\
\hline & $l$ & - & - & $15.0^{\mathrm{b}}$ & & & & & & & \\
\hline & $l$ & 97.7 & 3.5 & $1.30^{\mathrm{d}}$ & $17 / 22$ & 95 & 3.5 & $0.31^{\mathrm{f}}$ & $17 / 22$ & & \\
\hline & $u$ & - & - & & & & & & & & \\
\hline & $l$ & - & - & $-^{\mathrm{e}}$ & & & & & & & \\
\hline & $l$ & 82.6 & 6.3 & $0.41^{\mathrm{g}}$ & $5 / 22$ & 71.9 & 5.4 & $1.11^{\mathrm{i}}$ & $5 / 22$ & & \\
\hline & $u$ & - & - & & & & & & & & \\
\hline & $l$ & - & - & $-{ }^{\mathrm{h}}$ & & & & & & & \\
\hline \multirow[t]{3}{*}{ Jadeitite (MVE04-44-4) } & $l$ & 73 & 56 & $7.8^{\mathrm{a}}$ & $10 / 10$ & 86.4 & 3.7 & $1.80^{\mathrm{c}}$ & $10 / 10$ & $0.03-0.15$ & SHRIMP-RG \\
\hline & $u$ & 1590 & 3500 & & & & & & & & \\
\hline & $l$ & 87.2 & 4.1 & $7.0^{\mathrm{b}}$ & & 92.9 & 4.6 & $0.42^{\mathrm{f}}$ & $3 / 10$ & & \\
\hline \multicolumn{12}{|l|}{ Central North Motagua Mélange } \\
\hline \multirow{2}{*}{ Jadeitite (GJ) } & $l$ & 95.1 & 3.6 & 6.7 & $13 / 14$ & 94.1 & 3.9 & 6.7 & $13 / 14^{j}$ & $<0.005$ & SHRIMP-RG \\
\hline & $\mathrm{c}$ & 98.3 & 1.6 & 3.3 & $18 / 24$ & & & & & & \\
\hline \multirow[t]{2}{*}{ Jadeitite (MVE07B-3-1) } & $l$ & 84 & 14 & $3.80^{\mathrm{k}}$ & $8 / 8$ & - & - & - & - & $0.003-0.16$ & SHRIMP-RG \\
\hline & $u$ & 4956 & 120 & & & & & & & & \\
\hline \multirow[t]{2}{*}{ Mica-albite rock (MVE07B-4-2; T01-T02) } & $l$ & 90.5 & 8.1 & $3.10^{\mathrm{k}}$ & $32 / 32$ & - & - & - & - & $0.01-0.08$ & SHRIMP-RG \\
\hline & $u$ & 5085 & 89 & & & & & & & & \\
\hline \multirow[t]{2}{*}{ Mica-albite rock (MVE07B-4-2;T03) } & $l$ & 80.3 & 8 & $0.87^{\mathrm{k}}$ & $8 / 8$ & - & - & - & - & $0.01-0.07$ & LAM-ICP-MS \\
\hline & $u$ & 5000 & 160 & & & & & & & & \\
\hline \multirow[t]{2}{*}{ Mica-albite rock (MVE07B-5-4) } & $l$ & 82.5 & 8.6 & $1.60^{\mathrm{k}}$ & $8 / 8$ & - & - & - & - & $0.01-013$ & LAM-ICP-MS \\
\hline & $u$ & 5087 & 78 & & & & & & & & \\
\hline \multicolumn{12}{|l|}{ South Motagua Mélange } \\
\hline Ph-jadeitite (MVE02-8-6) & $c$ & 153.7 & 3.5 & 2 & $8 / 9$ & - & - & - & - & $\begin{array}{l}0.04-2.57 \\
(0.04-0.93)^{l}\end{array}$ & $\begin{array}{l}\text { LA-ICP-MS } \\
\text { and SIMS }\end{array}$ \\
\hline \multirow[t]{9}{*}{ Ph-jadeitite (MVE02-8-6) } & $l$ & 142 & 13 & $3.70^{\mathrm{a}}$ & $16 / 17$ & 142.2 & 8.4 & $1.6^{\mathrm{c}}$ & $16 / 17$ & $0.02-0.77$ & SHRIMP-RG \\
\hline & $u$ & 3793 & 4400 & & & & & & & & \\
\hline & $l$ & 147.2 & 9 & $5.90^{\mathrm{b}}$ & & & & & & & \\
\hline & $l$ & 150 & 12 & $0.70^{\mathrm{d}}$ & $9 / 17$ & 157.1 & 8.9 & $0.20^{f}$ & $7 / 17$ & & \\
\hline & $u$ & 2415 & 1400 & & & & & & & & \\
\hline & $l$ & 158 & 4.6 & $0.83^{\mathrm{e}}$ & & & & & & & \\
\hline & $l$ & 127.9 & 5.9 & $1.13^{\mathrm{g}}$ & $7 / 17$ & 128.8 & 8.4 & $0.28^{\mathrm{i}}$ & $7 / 17$ & & \\
\hline & $u$ & 3777 & 1800 & & & & & & & & \\
\hline & $l$ & 129.7 & 4.3 & $1.05^{\mathrm{h}}$ & & & & & & & \\
\hline
\end{tabular}

$n^{u}$ is the number of analyses used in the regression and $n^{t}$ is the total number of analyses for the sample; $l$ indicates the lower intercept age and $u$ the upper intercept age; $c$ correspond with a Concordia age; (a) U-Pb ages calculated using a regression of all good data points and no fixed upper intercept of ${ }^{207} \mathrm{~Pb} /{ }^{206} \mathrm{~Pb}$; (b) U-Pb ages calculated using a regression of all good data points and an upper intercept fixed at a chosen ${ }^{207} \mathrm{~Pb} /{ }^{206} \mathrm{~Pb}$ value (for all regressions we used $0.8283 \pm 0.05$ after Sañudo-Wilhelmy and Flegal,(1994)); (c) Tera-Wasserburg Model Age for all good data points. Tera-Wasserburg Model Age is a calculated weighted average age of all Tera-Wasserburg model ages. The latters were calculated as a single regression for each data point using fixed upper intercept at a chosen ${ }^{207} \mathrm{~Pb} /{ }^{206} \mathrm{~Pb}$ value; (d, e, f) and (g, h, i) are equivalent to (a, b, c) but calculated for a coherent groups of older and younger data points, respectively; (j) Weighted average age; (k) is equivalent to (a) but for all data points; and (l) Th/U ratio using 4 of the 5 total points.

respectively. Zircon ages range from 79 to $96 \mathrm{Ma}$ and do not define a clear age regression line (Fig. 3c). Moreover, data from this sample also display two possible age groups that are similar to those observed for sample MVE04-44-1. Three zircons that cluster into the older concordant group of MVE04-44-1 yield a model age of $92.9 \pm 4.6 \mathrm{Ma}$ (Fig. 3d). Nonetheless, probably more reliable ages are given by the rare large oscillatory zoned P1-01 zircon (Fig. 2i), which yields a well-defined core age of $96 \mathrm{Ma}$ and rim ages of 88-85 Ma. The chondrite-normalized REE patterns are characterized by depleted LREE, enriched HREE, an absence of Eu anomalies (except zircon P1-04), and strong positive Ce anomalies (Fig. 5b).

\subsection{Central North Motagua Mélange jadeitite and mica-albite rocks}

MVE07B-3-1: The eight zircons analyzed from this jadeitite range in size from 15 to $70 \mu \mathrm{m}$. They are stubby subhedral crystals, and their $\mathrm{CL}$ images show patchy zoning (Appendix 1 and Fig. A1.3). $\mathrm{U}$ and $\mathrm{Y}$ contents are relative low and range from 5 to $74 \mathrm{ppm}$ and from 28 to $826 \mathrm{ppm}$, respectively. The Th/U ratios range is $0.003-0.16$.
All the analyses are characterized by high $\mathrm{Pb}_{\mathrm{c}}$ and yield discordant $\mathrm{Pb}_{\mathrm{c}}$-uncorrected $\mathrm{U}-\mathrm{Pb}$ ages with a lower intercept at $84.0 \pm 14 \mathrm{Ma}$ (Fig. 4a). The chondrite-normalized REE patterns are somewhat more depleted than those from both jadeitites discussed above (Fig. 5c) with the exception of zircon D-07 that shows an upward shift from $\mathrm{Nd}$ to Gd. Only one zircon shows a negative Eu anomaly and one a positive Ce (Zrn F-01) anomaly.

MVE07B-4-2: Zircons from this mica-albite sample were analyzed three times, twice by the SHRIMP-RG (mounts T01 and T02) using two different thin sections and once by LAM-ICP-MS (mount T03) using a third section. The eight zircons from mount T01 are stubby subhedral crystals with a uniform size of $35-40 \mu \mathrm{m}$. CL images reveal predominantly patchy zoning; however, some crystals exhibit growth and sector zoning or no zoning (Appendix 1 and Fig. A1.4). Likewise, the 16 zircons from mount T02 are also stubby subhedral crystals with a size range from 10 to $80 \mu \mathrm{m}$. Their CL images show patchy, growth zoning and one unzoned crystal (Appendix 1 and Fig. A1.5). Finally, the eight zircons from mount T03 are stubby subhedral crystals with sizes 
a

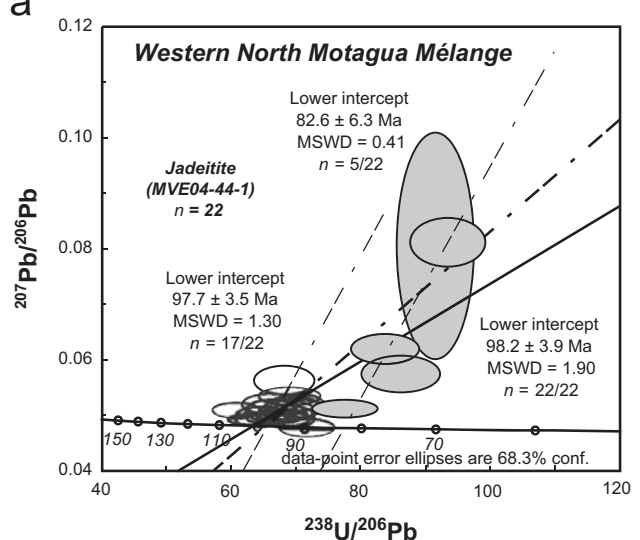

C

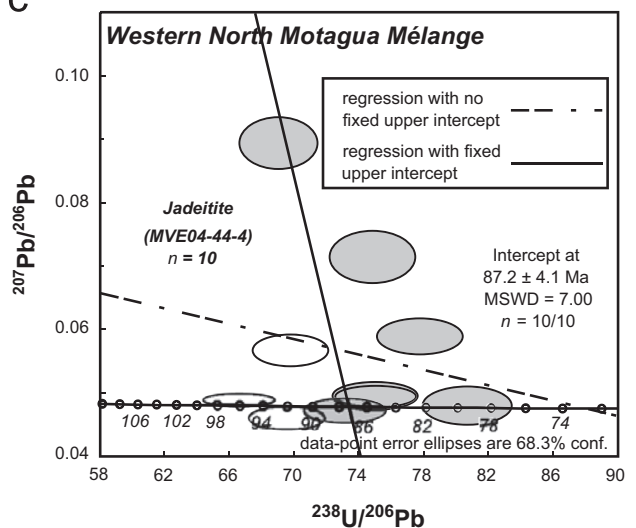

e

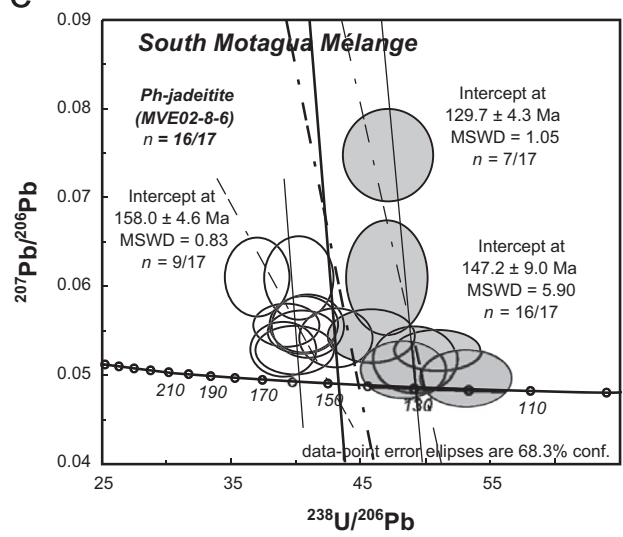

b

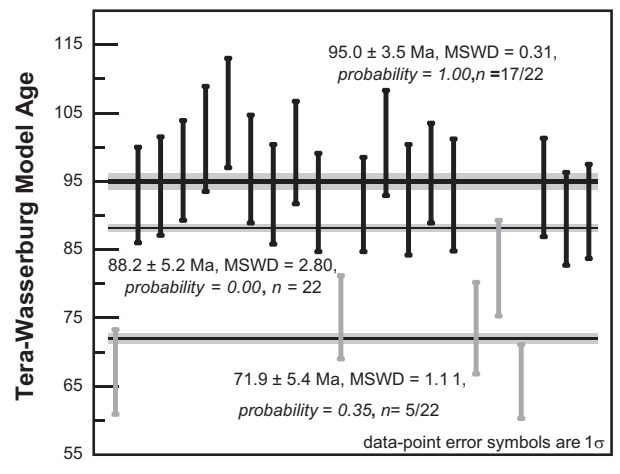

d

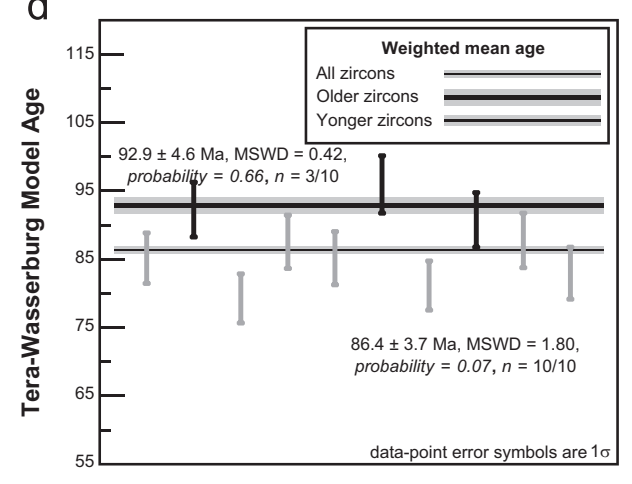

f

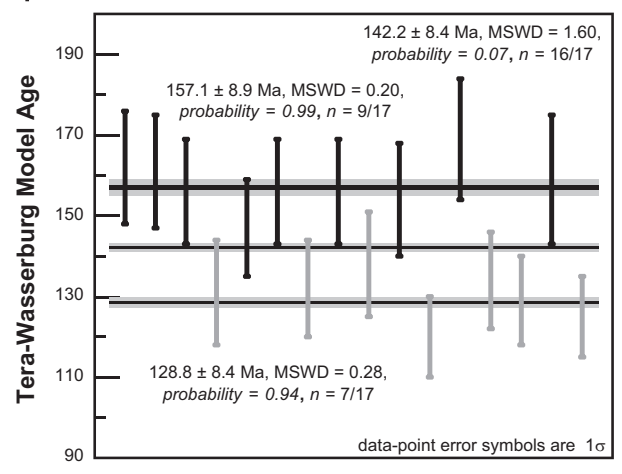

Fig. 3. Tera-Wasserburg concordia (after Tera and Wasserburg, 1972; Williams, 1998) and Tera-Wasserburg Model Age diagrams showing U-Pb SHRIMP zircon ages from three GSZ jadeitites. Details of the data reduction and regressions are given in Table 2 and Appendix 2. Note the occurrence of at least two groups of age populations in all samples represented by white and grey ellipses. Tera-Wasserburg model age diagrams show a weighted average age for all shown data points, as well as for each age group.

ranging from 40 to $70 \mu \mathrm{m}$. CL images exhibit patchy zoning, but one shows concentric zoning (Zrn a17D; Appendix 1 and Fig. A1.6). Uranium contents and $\mathrm{Th} / \mathrm{U}$ ratios in all three mounts are relatively low, from 1 to $57 \mathrm{ppm}$ and 0.01 to 0.08 , respectively. The Y values for T01 and T02 range from 6 to $730 \mathrm{ppm}$. Almost all analysis are characterized by high $\mathrm{Pb}_{\mathrm{c}}$ content and yield overlapping $\mathrm{Pb}_{\mathrm{c}}$-uncorrected $\mathrm{U}-\mathrm{Pb}$ lower intercept ages of $90.5 \pm$ 8.1 Ma (SHRIMP-RG T01 and T02 combined data, Fig. 4b) and $80.3 \pm 8.0 \mathrm{Ma}$ (T03, LAM-ICP-MS data, Fig. 4c). Nonetheless, zircon A from T02 (Appendix 1 and Figs. A1.5d and A1.5e) has a low $\mathrm{Pb}_{\mathrm{c}}(<5 \%)$ and yields a well-constrained $\mathrm{U}-\mathrm{Pb}$ age of $103.2 \pm$ 8.0 Ma. The above discussed ages suggest that this sample has the same range of ages as the well-constrained jadeitites from Section 5.1. Furthermore, the chondrite-normalized REE patterns (T01 and T02; Fig. 5d) are characterized by depleted LREE, enriched HREE, positive Eu anomalies (except T01, Zrn D1), and few positive Ce anomalies (T01 $n=2$ of 8 and T02 $n=3$ of 16).

MVE07B-5-4: The eight zircons analyzed from this mica-albite sample are stubby to semi-prismatic, subhedral, ranging in size from 15 to $50 \mu \mathrm{m}$. They too have low $\mathrm{U}$ contents from 9 to $19 \mathrm{ppm}$, low $\mathrm{Th} / \mathrm{U}$ ratios of 0.01 to 0.13 , and $\mathrm{U}-\mathrm{Pb}$ data characterized by high content of common $\mathrm{Pb}$. The zircons yield a $\mathrm{Pb}_{\mathrm{c}}$-uncorrected U-Pb lower intercept age of $82.5 \pm 8.6 \mathrm{Ma}$ (LAM-ICP-MS, Fig. 4d) that is similar to that from MVE07B-4-2 T03 but slightly younger, within error, than the combined T01 and T02 SHRIMP-RG age.

\subsection{South Motagua Mélange phengite jadeitite}

Zircons from phengite-jadeitite sample MVE02-8-6 are euhedral to subhedral with stubby to prismatic habit and sizes from 10 
a

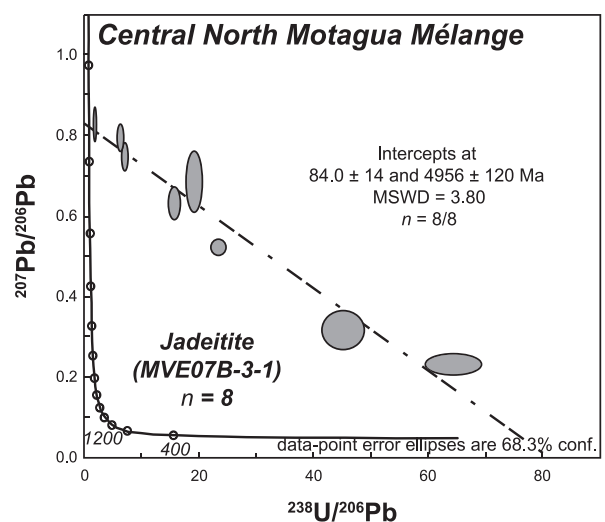

C

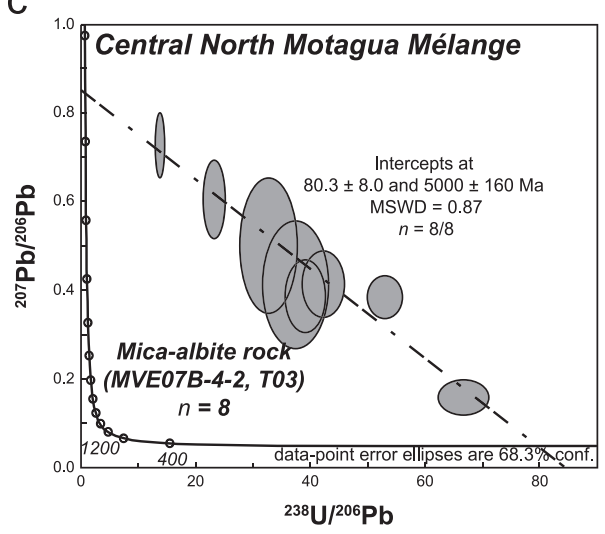

b

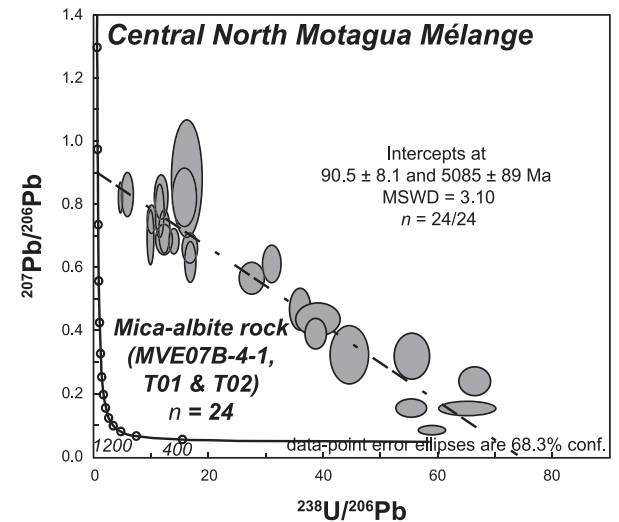

d

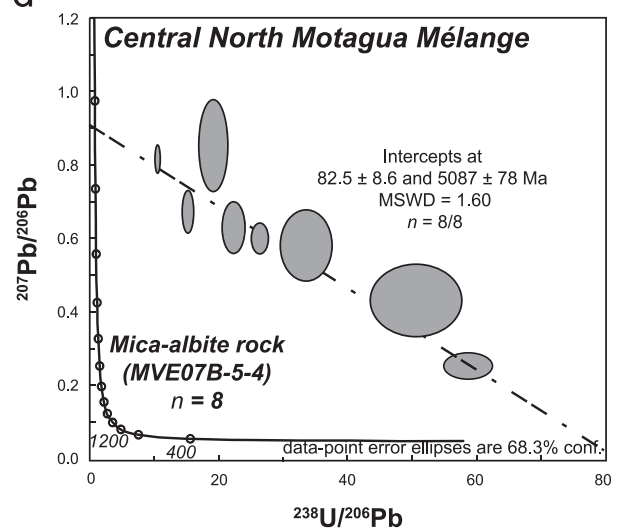

Fig. 4. Tera-Wasserburg concordia diagrams showing U-Pb SHRIMP (Fig. 4a and b) and LAM-ICP-MS (Fig. 4c and d) zircon ages of one jadeitite and two mica-albite rocks from the NMM. Details of the data reduction and regressions are given in Table 2, Appendices 2 and 3. Due to the high content of common lead, uncorrected ${ }^{207} \mathrm{~Pb} /{ }^{206} \mathrm{~Pb}$ was used in these diagrams which only provide a general idea of the age of the studied rocks. Nonetheless, these ages, within errors, are consistent with the well constrained ages reported in Fig. 3.

to $40 \mu \mathrm{m}$. CL images show concentric growth, patchy, or no zoning (Appendix 1 and Fig. A1.7). The $U$ and $Y$ concentrations range from 186 to $1457 \mathrm{ppm}$ and from 670 to $11,160 \mathrm{ppm}$, respectively. This jadeitite shows the largest range in $\mathrm{Th} / \mathrm{U}$ ratios $(0.02-0.80)$, with an average of $0.38(\sigma=0.25)$. Individual $\mathrm{U}-\mathrm{Pb}$ ages range from 120-172 Ma and define lower intercept and model ages of 142 and 147 Ma when regressing all analyses (Fig. 3e and f). However, data from this sample show two, relatively well-constrained age groups. An older group yields both lower intercept and model ages of $\sim 158 \mathrm{Ma}$, and a younger group yields intercept and model ages of 128 and $130 \mathrm{Ma}$, respectively. The chondrite-normalized REE patterns (Fig. 5e) show depleted LREEs, enriched HREEs, negative $\mathrm{Eu}$ anomalies, positive $\mathrm{Ce}$ anomalies. These patterns are enriched relative to their NMM counterparts and show an intermediate composition with respect to REE patterns from (a) an eclogite facies vein (Qtz-Omp-Ph) from the Sesia-Lanzo Zone in the Alps (Rubatto, 2002) and (b) a gabbro from the Atlantic Massif in the Mid-Atlantic Ridge (Grimes et al., 2007).

\section{Discussion}

\subsection{Origin of the GSZ jadeitite and mica-albite rock zircons}

Determining the origin of zircons in the studied rocks is critical to interpreting their dates. Did the zircons form at the same time the host jadeitite or albitite crystallized (metamorphic or hydrothermal fluid crystallization) or are they inherited from a possible igneous or sedimentary protolith? Several criteria that have been used to distinguish primary metamorphic/hydrothermal zircons from igneous relicts include (a) internal texture (CL image), (b) Th/U ratios, (c) chondrite-normalized zircon REE patterns (Eu depletion, Ce enrichment, $\mathrm{P}, \mathrm{Ti}, \mathrm{Y}, \mathrm{Nb}$ and $\mathrm{Hf}$ concentrations), (d) oxygen isotopes $\left(\delta^{18} \mathrm{O}\right.$ and $\left.\Delta^{18} \mathrm{O}\right),(\mathrm{e}) \mathrm{Hf}$ isotopes $\left(\varepsilon \mathrm{Hf}(t),{ }^{176} \mathrm{Hf} /{ }^{177} \mathrm{Hf}\right.$ and $\left.{ }^{176} \mathrm{Lu} /{ }^{177} \mathrm{Hf}\right)$, and (f) the occurrence and nature of inclusions (e.g., Fu et al., 2010, 2012; Rubatto, 2002; Shi et al., 2009; Yui et al., 2010, 2012). Yui et al. $(2010,2012)$ used some of these criteria to interpret zircons from a jadeitite locality near MVE07B-3-1 in the central NMM as being of metasomatic/solution-precipitate origin (i.e., hydrothermal) whereas Fu et al. (2010) interpreted zircons from a SMM phengite-jadeite as a mix of metasomatic and inherited-igneous origin.

$\mathrm{CL}$ images show that approximately half of the zircon crystals have dark homogenous interiors and rhythmic overgrowths, while the other half has patchy or complex crystal zoning patterns (Appendix 1 and Fig. 2). Rhythmic zoning is typically used as an argument for an igneous origin, but it actually indicates growth from a fluid without a distinction as to whether the fluid is silicate melt or hydrothermal fluid (Schertl et al., 2012).

$\mathrm{Th} / \mathrm{U}$ ratios are considered a strong discriminator of origin for zircons because of the relatively low solubility of Th in hydrous fluid compared to melt. Low Th/U ratios in zircons therefore have been used as a signature of metamorphic/hydrothermal origin, particularly in relation to jadeitite (Fu et al., 2010; Rubatto, 2002; Tsujimori et al., 2005; Yui et al., 2010, 2012). However, these criteria are now considered unreliable discriminants for zircon origin, because they do not take in account several factors that affect the Th/U ratios, such as the order of crystallization of $U$ and Th-rich minerals (e.g., monazite, allanite), the PT conditions of crystallization (or recrystallization) of zircons, and the mineral-fluid interaction processes (Harley et al., 2007). Most of the Th/U values 
a
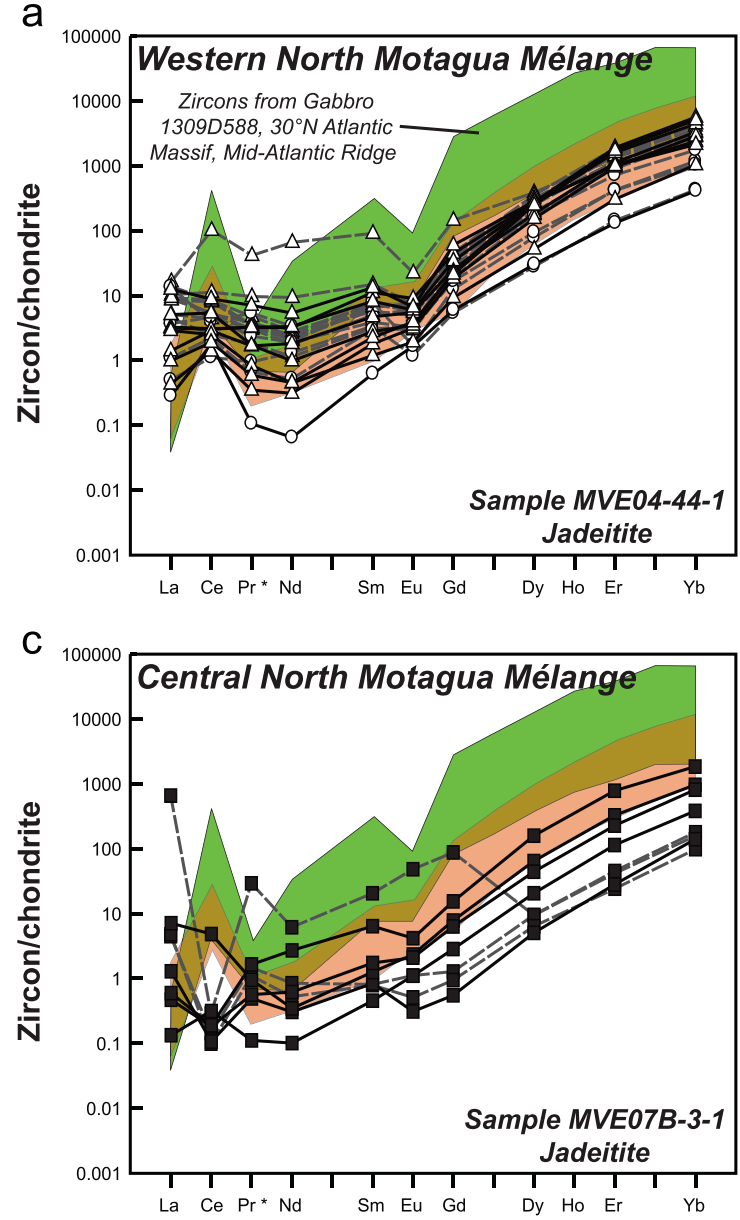

d

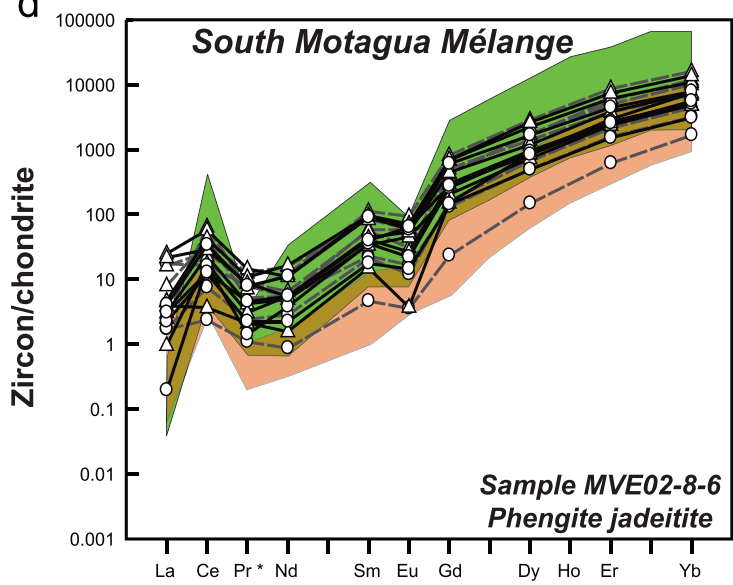

b

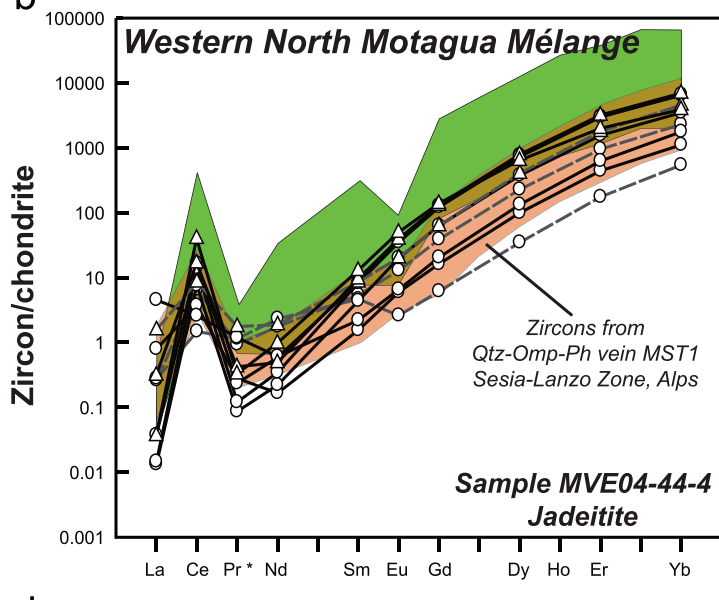

d

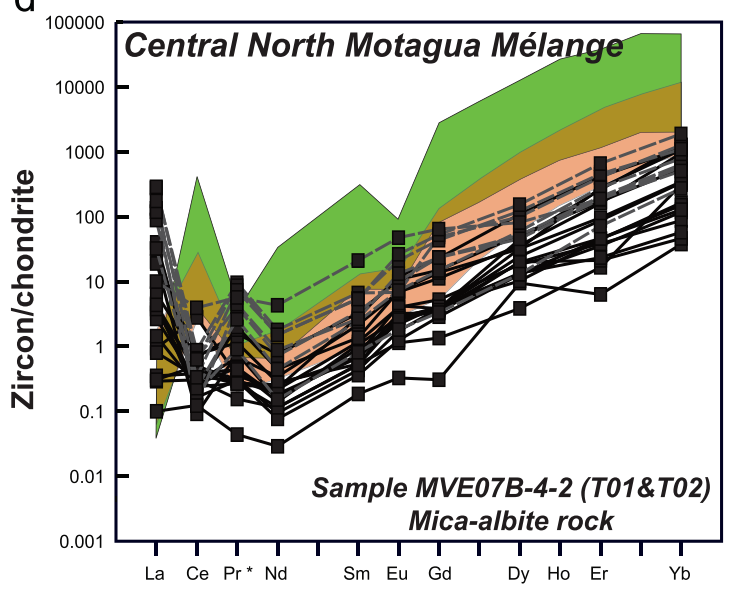

Zircon sizes

Zircon size $\geq$ beam size

Zircon size $<$ beam size

$\underline{\mathrm{U}-\mathrm{Pb} \text { ages }}$

$\triangle \quad$ Older zircons $\left(\mathrm{Pb}_{\mathrm{c}}<5 \%\right)$

Y Younger zircons $\left(\mathrm{Pb}_{\mathrm{c}}<5 \%\right)$

Not well-constrained ages $\left(\mathrm{Pb}_{\mathrm{c}}>5 \%\right)$

Fig. 5. Chondrite-normalized REE patterns for zircons from four jadeitites and one mica-albite rock from the Guatemala Suture Zone compared to zircon REE patterns from eclogite facies vein (Qtz-Omp-Ph) from the Sesia-Lanzo Zone in the Alps (Rubatto, 2002) and gabbro from the Atlantic Massif in the Mid-Atlantic Ridge (Grimes et al., 2007). The $\operatorname{Pr}^{*}=\left(\mathrm{La}^{*} \mathrm{Nd}^{2}\right)^{1 / 3}$ and chondrite normalization values are after McDonough and Sun (1995).

measured in this study are low $(<0.1)$, except for some in the SMM phengite jadeitite (MVE02-8-6), which includes somewhat higher values $(0.02-0.80, n=17)$ although not as high as the five values reported by Fu et al. (2010). It is important to note that MVE02-8-6 also contains monazite and allanite in the primary assemblage; therefore, the $\mathrm{Th} / \mathrm{U}$ ratios of zircon from this sample depended on the effect of monazite/allanite crystallization, and so these low ratios should not necessarily be interpreted as indicating an inherited origin.

As noted above, zircon chondrite-normalized REE patterns from the jadeitite and mica-albite rock from this study are depleted relative to those of zircons from oceanic gabbros, with the exception of sample MVE02-8-6, which shows a somewhat less depleted pattern (Fig. 5e). Some zircons also exhibit typical igneous characteristics such as positive $\mathrm{Ce}$ and negative $\mathrm{Eu}$ anomalies. However, these zircons, with these "igneous signatures", do not give older ages, and/or high Th/U ratios that would be expected if they had an igneous origin. Moreover, abundances of certain elements, such as $U$ and $Y$, appear to vary from sample to sample from the same locality as well as from locality to locality. For example, $U$ is highest in zircons from the western NMM, intermediate in SMM zircons, and highly depleted in zircons from samples from the central NMM. 
Most of the zircons studied here contain fluid and/or mineral inclusions that record the primary mineralization (i.e., jadeite, omphacite, and zoisite) and fluid crystallization of the host rock (Table 1). Only one altered jadeitite (MVE07B-3-1) contains zircons hosted in what might be a somewhat late-stage phase, Ab. The inclusions are clearly consistent with crystallization from a fluid under HP-LT conditions, rather than having an origin as an igneous zircon. Furthermore, zircons from most samples occur as small clusters of euhedral crystals (e.g., Fig. 2d), which suggests a primary texture, rather than an inherited one, where the zircons might be expected to be randomly distributed. Therefore, we interpret all the analyzed zircons from this study as having a syn-crystallization hydrothermal origin.

Fu et al. (2010) proposed a mixed origin, i.e., both hydrothermal and inherited, for zircons from the SMM jadeitite. Their interpretation used several criteria: (a) high igneous $\delta^{18} \mathrm{O}$ values, (b) similarity of REE patterns to those of igneous zircon, and (c) a U-Pb zircon age (154 Ma) older than the metamorphic and exhumation ages of HP-LT rocks from the same unit (144-132 Ma; Brueckner et al., 2009). The range of $\Delta^{18} \mathrm{O} \mathrm{Jd}$-Zrn values observed by $\mathrm{Fu}$ et al. (2010) is 2.2-3.0 (average $=2.6$ ), which is consistent with $T=440-568{ }^{\circ} \mathrm{C}$ (average $=503{ }^{\circ} \mathrm{C}$ ) from their own arguments. These temperature estimates overlap those calculated for the formation of lawsonite-absent jadeitites from SMM, such as MVE02-8-6, which are estimated at $450-500{ }^{\circ} \mathrm{C}$ (Harlow et al., 2011). We do not view these temperatures estimates as significantly different; quite the contrary, they match, and could equally well be estimates of hydrothermal fluid temperatures as melt temperatures. Second, the similarity of the REE patterns to those of igneous rocks is not in itself a reason to deduce an igneous origin. Third, the pre-HP metamorphic crystallization ages of the jadeitite zircons, which we verify in this study, can equally well be explained by processes other than an igneous one as we discuss in more detail below.

\subsection{Age interpretation and tectonic implications for the GSZ}

The zircon U-Pb dates (Table 2) reported here are consistent with the previously reported ages of Fu et al. (2010) and Yui et al. $(2010,2011)$ and further document the earlier formation of jadeitite relative to when the mélange metabasites reached their metamorphic peak and underwent exhumation.

North of the MFS the eclogite samples from the western NMM region yield Sm-Nd mineral isochrons of 125 and $131 \mathrm{Ma}$ (see above), not significantly different from the eclogite south of the MFS. The well-constrained zircon ages from the jadeitite from two regions of the NMM, on the other hand, now span 98-95 and 87-72 Ma (Table 2). Clearly, jadeitites formed 25-55 Ma later than the early Cretaceous eclogites from the same mélange (Table 3; Fig. 6a and b). However, there is considerable evidence for a second, younger, major HP-LT event in the mélange as well as a HP-HT event in the continental crust of the Maya Block at $\sim 76 \mathrm{Ma}$ (see above). This age is within the upper limit of the $\mathrm{Ar}-\mathrm{Ar}$ ages of 76-62 and 77-53 Ma of micas and amphiboles from the Chuacús complex and micas from jadeitites, albitites and mica rocks from the NMM (Harlow et al., 2004; Ratschbacher et al., 2009 and references therein). The U-Pb dates reported here from jadeitite and mica-albite rock zircons are $\sim 50 \mathrm{Ma}$ younger than the $\sim 128 \mathrm{Ma}$ eclogite-facies metamorphism from the western NMM but overlap or are slightly older $(\sim 22-4 \mathrm{Ma})$ than the second HP-LT event (Fig. 6c). Thus, it is probable that jadeites and micaalbite rocks from the NMM are genetically related to the later HP-LT tectonic event. The older Sm-Nd ages reported from eclogites at the western margin of the NMM represent either a different tectonic event or some other tectonic complexity that requires further study.
The maximum age of eclogite metamorphism south of the MFS, is dated at 144-132 Ma (Brueckner et al., 2009), 26-14 Ma younger than jadeitite zircon crystallization dates of 154-158 Ma. In addition, we also have the suggestion of a second younger event with a mean age of $130-128 \mathrm{Ma}$, which is slightly older than the 125-113 Ma phengite $\mathrm{Ar}-\mathrm{Ar}$ reported from jadeitites and eclogites in the same mélange (Harlow et al., 2004). The origin and validity of these second younger ages is unclear and could be related to (a) resetting of zircon prior to or during exhumation, and/or (b) possibly related to another generation of zircon crystallization. In fact, the range in ages may simply reflect the duration of the entire jadeitite crystallization process.

\subsection{Tectonic scenario for the formation of vein-related jadeitites}

The working hypothesis for formation of jadeitite in Guatemala (both NMM and SMM) involves vein crystallization from subduction channel fluids filling fractures in the overlying mantle wedge (Harlow et al., 2007, 2011; Harlow and Sorensen, 2005; Sorensen et al., 2006; Tsujimori and Harlow, 2012) at depths of 20-70 km. Thus, jadeitite is deposited in the relatively static zone of the shallow, brittle wedge, rather than in the down-going slab, which contains the HP-LT metabasites (e.g., eclogite, blueschist). Jadeitite can thus form and remain stored under HP-LT conditions for a significant period before being exhumed by a subsequent major tectonic event (e.g., collision and slab detachment), which then mixes the jadeitite in a mélange along with more recently formed HP-LT metabasites that escaped ultimate subduction. If this model is correct, jadeitites are a direct record of fluid infiltration and mass transfer into the mantle wedge during active subduction.

There are other examples from the meager record of jadeitite in Earth history. As pointed out by Tsujimori and Harlow (2012), zircons from Japanese Paleozoic jadeitites (Omi and Osayama) are more than $\sim 200-180$ Ma older than the associated Late Paleozoic HP-LT schists (Table 3; Kunugiza and Goto, 2010; Tsujimori et al., 2005), although there may be some question about the dates from the schists being an appropriate age bracket. The same relationship has been described at the Jade mine tract (Myanmar), where the $163-146 \mathrm{Ma}$ jadeitite formation age indicated by the U-Pb zircon data (Table 3; Qiu et al., 2009; Shi et al., 2008) is much older than the composite phengite $\mathrm{Ar}-\mathrm{Ar}$ age of $80-30 \mathrm{Ma}$ (Goffé et al., 2002); however, the earlier formation $\mathrm{Zrn}$ age here is disputed as being inherited from protoliths (Yui et al., 2013).

A contrasting example to the complexes described above is the Syum-Keu and Marun-Keu belts of the Polar Urals (Russia) wherein zircon ages from jadeitite of the first unit are only $\sim 38$ $-28 \mathrm{Ma}$ older than the $\mathrm{Sm}-\mathrm{Nd}, \mathrm{U}-\mathrm{Pb}$ and $\mathrm{Rb}-\mathrm{Sr}$ mineral ages from eclogites of the second complex (Fig. 6d; Shatsky et al., 2000; Glodny et al., 2003, 2004; Meng et al., 2011). A similar example comes from HP-LT rocks from the Río San Juan Complex, where a $115 \mathrm{Ma} \mathrm{U}-\mathrm{Pb}$ age from zircon cores on the quartz-free jadeitite is $\sim 11$ Ma older than the 104 Ma metamorphic peak given by Lu-Hf on eclogite, and, the younger $93 \mathrm{Ma}$ age from zircon rims on jadeitites is also older than the $\sim 75-73 \mathrm{Ma}$ exhumation age (see Fig. 6e and Table 3; Krebs et al., 2008; Schertl et al., 2012). However, the context of this type of jadeitite is not clear; perhaps not being serpentinite hosted, and thus may not be analogous despite the age difference similarity. These timing relationships are similar to those in the SMM and the NMM of the GSZ where crystallization of jadeitites are up to 25 million years older than the metamorphic peak age of metabasite from the same complexes (see Figs. 6a, 5b and $\mathrm{c}$ and Table 3 ). It appears that the four well-constrained jadeitite-bearing complexes discussed above share a similar tectonic scenario for the formation and exhumation of jadeitite. 
Table 3

Geochronology and PT conditions summary of dated jadeitites and related HP-LT metamorphic rocks of the world.

\begin{tabular}{|c|c|c|c|c|}
\hline Tectonic unit & $\begin{array}{l}\text { Jadeitite and related } \\
\text { rocks } \mathrm{U}-\mathrm{Pb} \text { age (Ma) }\end{array}$ & HP-LT metamorphic ages (Ma) & $P T$ conditions & Key references \\
\hline $\begin{array}{l}\text { Syum-Keu ultramafic } \\
\text { complex, Polar } \\
\text { Urals, Russia }\end{array}$ & $\begin{array}{l}\text { Age range groups } \\
414-368(n=13) \\
\text { Th/U } \\
0.03-0.21(n=13)\end{array}$ & $\begin{array}{l}\text { (a) } 375.6 \pm 6.1 \text { to } 360.7 \pm 5.9 \text { (Zrn U-Pb in } \\
\text { eclogite-facies vein); } 366 \pm 8.5 \text { (Sm-Nd in } \\
\text { Gln-eclogite); and } 339 \pm 16 \text { (Sm-Nd in } \\
\text { Ky-eclogite) } \\
\text { (b) } 357.3 \pm 6.6 \text { to } 353.3 \pm 3.1(\mathrm{Rb}-\mathrm{Sr} \text { in } \\
\text { eclogite and eclogite-facies vein); } 357.9 \pm 3.7 \\
\text { to } 353 \pm 6 \text { (Rb-Sr in retrograde amphibolite) }{ }^{1} \\
\text { (c) } 347-346 \text { (Amp and Ms K-Ar in } \\
\text { blueschist) }\end{array}$ & $\begin{array}{l}\text { (d) } \sim 600-650{ }^{\circ} \mathrm{C} \\
\text { and } \sim 1.4-1.7 \mathrm{GPa}^{1}\end{array}$ & $\begin{array}{l}\text { Glodny et al. (2003, 2004), } \\
\text { Meng et al. (2011), Molina et al. (2002), } \\
\text { Shatsky et al. (2000), Udovkina (1985) }\end{array}$ \\
\hline $\begin{array}{l}\text { Omi serpentinite } \\
\text { mélange (Renge } \\
\text { metamorphic } \\
\text { belt/Hida marginal } \\
\text { zone), Japan }\end{array}$ & $\begin{array}{l}\text { Mean } 519 \pm 17(n=1) \text { and } \\
512.3 \pm 6.9(n=1)\end{array}$ & $\begin{array}{l}\text { (a) - } \\
\text { (b) - } \\
\text { (c) } 348 \text { and } 343(\mathrm{Ph} \mathrm{K-Ar} \mathrm{and} \\
\text { Ar-Ar in Gln-eclogite) })^{2}\end{array}$ & $\begin{array}{l}(\boldsymbol{d})-\sim 550-600{ }^{\circ} \mathrm{C} \\
\text { and } \sim 1.8-2.1 \mathrm{GPa}^{2} \\
(\boldsymbol{e})-\end{array}$ & $\begin{array}{l}\text { Tsujimori (2002), Tsujimori and } \\
\text { Matsumoto (2006), Tsujimori et al. (2001), } \\
\text { Kunugiza and Goto (2010) }\end{array}$ \\
\hline $\begin{array}{l}\text { Osayama } \\
\text { serpentinite } \\
\text { mélange (Renge } \\
\text { metamorphic } \\
\text { belt/Oeyama belt), } \\
\text { Japan }\end{array}$ & $\begin{array}{l}\text { Mean } 472 \pm 8.5(n=25) \\
\text { Age range groups } 523-488 \\
(n=2) ; \text { and } 521-451(n=25) \\
\text { Th/U } 0.76-0.82(n=2) ; \text { and } 0.21- \\
0.73(n=25)\end{array}$ & $\begin{array}{l}\text { (a) - } \\
\text { (b) - } \\
\text { (c) ca. } 320 \text { ( } 327-273 ; \text { Ph K-Ar in pelitic and } \\
\text { basic blueschist-facies blocks) }\end{array}$ & $\begin{array}{l}\text { (d) } \sim 480-550{ }^{\circ} \mathrm{C} \\
\text { and } \sim 1.1-1.3 \mathrm{GPa} \\
\text { (e) }<350{ }^{\circ} \mathrm{C} \text { and } \\
>1.2 \mathrm{GPa}\end{array}$ & $\begin{array}{l}\text { Tsujimori and Itaya (1999), Tsujimori and } \\
\text { Liou (2004), Tsujimori et al. (2005) }\end{array}$ \\
\hline $\begin{array}{l}\text { Jade tract, Jade Mines } \\
\text { belt, Myanmar }\end{array}$ & $\begin{array}{l}\text { Mean } 163.2 \pm 3.3(n=18) ; \\
158 \pm 2(n=75) ; \text { and } 146.5 \pm 3.4 \\
(n=10) \\
\text { Age range groups } 175-153 \\
(n=18) ; 189-148(n=75) ; 158- \\
140(n=10) ; \text { and } 122.2(n=1) \\
\text { Th/U } 0.05-0.31(n=18) ; 0.01- \\
0.34(n=75) ; 0.07-0.18(n=10) ; \\
\text { and } 0.07(n=1)\end{array}$ & $\begin{array}{l}\text { (c) } 80-30(\mathrm{Ph} \mathrm{Ar}-\mathrm{Ar} \text { in eclogite and } \\
\text { blueschist) }\end{array}$ & $\begin{array}{l}\text { (e) } \sim 420{ }^{\circ} \mathrm{C} \text { and } \\
\sim 1.4-1.6 \mathrm{GPa}\end{array}$ & $\begin{array}{l}\text { Goffé et al. (2002), Qiu et al. (2009); } \\
\text { Oberhänsli et al. (2007), Shi et al. (2001, } \\
\text { 2003, 2008) }\end{array}$ \\
\hline $\begin{array}{l}\text { South Motagua } \\
\text { Mélange, } \\
\text { Guatemala }\end{array}$ & $\begin{array}{l}\text { Mean } 153.7 \pm 3.5(n=8) \\
158 \pm 4.6(n=10) ; \text { and } \\
129.7 \pm 4.3(n=7) \\
\text { Age range groups } \\
160-134(n=9) ; \text { and } 172-120 \\
(n=17) \\
\text { Th/U } 0.04-2.57(n=5) ; 0.02-0.77 \\
(n=17) ;\end{array}$ & $\begin{array}{l}\text { (b) - } \\
\text { (c) } 125-116(\mathrm{Ph} \mathrm{Ar}-\mathrm{Ar} \text { in jadeitite); } \\
\text { and } 120-113(\mathrm{Ph} \mathrm{Ar} / \mathrm{Ar} \text { in eclogite })\end{array}$ & $\begin{array}{l}\text { (e) } \sim 300-400{ }^{\circ} \mathrm{C} \\
\text { and } \sim 1.0-2.0 \mathrm{GPa}\end{array}$ & $\begin{array}{l}\text { Brueckner et al. (2009), Fu et al. (2010), } \\
\text { Harlow et al. (2004, 2011), } \\
\text { Tsujimori et al. (2006a, 2006b); This paper }\end{array}$ \\
\hline $\begin{array}{l}\text { Jagua Clara and } \\
\text { Arroyo Sabana } \\
\text { mélanges, Rio San } \\
\text { Juan Complex, } \\
\text { Dominican } \\
\text { Republic }\end{array}$ & $\begin{array}{l}\text { Mean } 114.9 \pm 2.9(n=5) ; \text { and } \\
93.3 \pm 6.9(n=4) \\
\text { Age range groups } 129-92(n=9)\end{array}$ & $\begin{array}{l}\text { (a) } 103.6 \pm 2.7 \text { (Lu-Hf in eclogite) } \\
\text { (b) } 139.13 \pm 1.1 \text { (Zrn U-Pb in eclogite); } \\
80.3 \pm 1.1 \text { (Rb-Sr in Omp-blueschist); and } \\
62.1 \pm 1.4(\mathrm{Rb}-\mathrm{Sr} \text { in Jd-blueschist) } \\
\text { (c) } 74.7 \pm 0.5(\mathrm{Rb}-\mathrm{Sr} \text { in eclogite); } \\
73.85 \pm 0.79 \text { (Ph Ar-Ar in Omp-blueschist); } \\
\text { and } 73.42 \pm 0.74 \text { (Ph Ar-Ar in eclogite) }\end{array}$ & $\begin{array}{l}\text { (e) } \sim 350-500{ }^{\circ} \mathrm{C} \\
\text { and } \sim 1.5-1.6 \mathrm{GPa}\end{array}$ & $\begin{array}{l}\text { Krebs et al. (2008, 2011), } \\
\text { Schertl et al. (2012) }\end{array}$ \\
\hline $\begin{array}{l}\text { Sierra del Convento } \\
\text { Mélange, Cuba }\end{array}$ & $\begin{array}{l}\text { Mean } 107.4 \pm 0.5(n=6) ; \text { and } \\
107.8 \pm 1.1(n=6) \\
\text { Age range groups } 108-107 \\
(n=9)\end{array}$ & $\begin{array}{l}\text { (a) - } \\
\text { (b) 126-120, 112.8, and 105-103 (Zrn U-Pb in } \\
\text { anatectic tonalitic-trondhjemite); and 116-82 } \\
\text { (Amp, Mca, Fsp and whole rock } \mathrm{K}-\mathrm{Ar} \text { in } \\
\text { Grt-amphibolite, anatectic tonalitic- } \\
\text { trondhjemite, mafic blueschist and mica } \\
\text { schist) } \\
\text { (c) } 106-97 \text { and } 87-83 \text { (Amp Ar-Ar in } \\
\text { Grt-amphibolite and anatectic } \\
\text { tonalitic-trondhjemite) }\end{array}$ & $\begin{array}{l}\text { (e) } \sim 550-625^{\circ} \mathrm{C} \\
\text { and } \sim 1.5 \mathrm{GPa}\end{array}$ & $\begin{array}{l}\text { Cárdenas-Párraga et al. (2012), García- } \\
\text { Casco et al. (2009), Hatten et al. (1989), } \\
\text { Lázaro et al. (2009), Somin and Millán } \\
\text { (1981), Somin et al. (1992) }\end{array}$ \\
\hline $\begin{array}{l}\text { North Motagua } \\
\text { Mélange, } \\
\text { Guatemala }\end{array}$ & $\begin{array}{l}\text { Mean } 95.0 \pm 3.5(n=17) \\
94.1 \pm 3.9(n=13) ; \text { and } \\
02.9 \pm 4.6(n=3) \\
\text { Age range groups } \\
105-70(n=22) ; 96-79(n=10) ; \\
110-58(n=8) ; 100-68(n=24) ; \\
\text { and } 118-41(n=24)^{4} \\
\text { Th/U } 0.01-0.07(n=22) ; 0.03- \\
0.15(n=10) ; 0.003-0.16(n=8) ; \\
<0.007(n=24) ; 0.01-0.08 \\
(n=32)^{4} ; \text { and } 0.01-0.13(n=8)^{4}\end{array}$ & $\begin{array}{l}\text { (a) } 130.7 \pm 6.3 \text { and } 125 \pm 7.8 \text { (Sm-Nd in } \\
\text { eclogite); } 77 \pm 13(\mathrm{Sm}-\mathrm{Nd} \text { in eclogite-facies } \\
\text { bands and boudins })^{5} \text {; and } 75.5 \pm 2(\mathrm{Zrn} \mathrm{U}-\mathrm{Pb} \\
\text { in eclogite-facies bands and boudins) } \\
\text { (b) - } \\
\text { (c) } 77-65 \text { ( } \mathrm{Ph} \mathrm{Ar-Ar} \mathrm{in} \mathrm{mica-albite} \mathrm{rock);} \mathrm{and} \\
75-53 \text { ( } \mathrm{Ph} \mathrm{Ar-Ar} \text { in jadeitite) }\end{array}$ & $\begin{array}{l}\text { (d) } \sim 600-650{ }^{\circ} \mathrm{C} \\
\text { and } \sim 2-2.3 \mathrm{GPa} ; \\
\text { and } \sim 700-800{ }^{\circ} \mathrm{C} \\
\text { and } \sim 2.1-2.4 \mathrm{GPa}^{5}\end{array}$ & $\begin{array}{l}\text { Brueckner et al. (2009), Harlow et al. (2004, } \\
\text { 2008, 2011), Martens et al. (2012), } \\
\text { Tsujimori et al. (2004), Yui et al. (2011, } \\
\text { 2012); This paper }\end{array}$ \\
\hline
\end{tabular}


Table 3 (continued)

\begin{tabular}{|c|c|c|c|c|}
\hline Tectonic unit & $\begin{array}{l}\text { Jadeitite and related } \\
\text { rocks } \mathrm{U}-\mathrm{Pb} \text { age (Ma) }\end{array}$ & HP-LT metamorphic ages (Ma) & $P T$ conditions & Key references \\
\hline \multirow{2}{*}{$\begin{array}{l}\text { Nishisonagi } \\
\text { metamorphic } \\
\text { rocks (Sambagawa } \\
\text { or Shimanto belts), } \\
\text { Japan }\end{array}$} & $\begin{array}{l}\text { Mean } 136.4 \pm 6(n=18) ; 126 \pm 6 \\
(n=45) ; \text { and } 84 \pm 6(n=14)\end{array}$ & (a) 93.2 (Gln $\mathrm{Ar}-\mathrm{Ar}$ in Gln-schist) & $\begin{array}{l}\text { (d) } \sim 440{ }^{\circ} \mathrm{C} \text { and } \\
\sim 0.8 \mathrm{GPa}\end{array}$ & $\begin{array}{l}\text { Faure et al. (1988a, 1988b), Itaya et al. } \\
\text { (2011), Mori et al. (2006, 2007, 2011), } \\
\text { Shigeno et al. (2005), Yui et al. (2012) }\end{array}$ \\
\hline & $\begin{array}{l}\text { Age range groups } 143-81 \\
(n=26) ; 139-114(n=44) ; \\
101-75(n=14) \\
\text { Th/U } 0.007-1.94(n=26) ; \\
0.48-1.64(n=49) ;<0.06 \\
(n=16)\end{array}$ & $\begin{array}{l}\text { (b) } 69.2 \text { (Bt } \mathrm{Ar}-\mathrm{Ar} \text { in Bt-basic schist); } \\
\text { 90.9 (Ph } \mathrm{Ar}-\mathrm{Ar} \text { in quartzite); } \\
\text { 90-80 (Ms } \mathrm{Ar}-\mathrm{Ar} \text { jadeitite) } \\
\text { (c) } 76.3(\mathrm{Ph} \mathrm{Ar}-\mathrm{Ar} \text { in Gln-schist); } 76 \text { (Rb-Sr in } \\
\text { jadeitite); } 67-63 \text { (Phl Ar-Ar in jadeitite) }\end{array}$ & $\begin{array}{l}(\boldsymbol{e})>400{ }^{\circ} \mathrm{C} \text { and } \\
>1.3 \mathrm{GPa}\end{array}$ & \\
\hline \multirow[t]{3}{*}{$\begin{array}{l}\text { Kampos mélange, } \\
\text { Syros and Tinos } \\
\text { Islands (Cycladic } \\
\text { blueschist belt), } \\
\text { Greece }\end{array}$} & $\begin{array}{l}\text { Mean } 62(n=4) ; 79.8 \pm 0.7 \\
(n=15) ; 77.9 \pm 0.12(n=4)^{6} ; \text { and } \\
79.8 \pm 0.5(n=7)^{6}\end{array}$ & (a) $52-50$ (Lu-Hf in eclogite) & $\begin{array}{l}\text { (d) } \sim 500{ }^{\circ} \mathrm{C} \text { and } \\
\sim 1.5 \mathrm{GPa}\end{array}$ & $\begin{array}{l}\text { Bröcker and Enders (1999, 2001), Bröcker } \\
\text { and Keasling (2006), Bulle et al. (2010), } \\
\text { Cheney et al. (2000), Keay (1998), Lagos } \\
\text { et al. (2007), Okrusch and Bröcker (1990), } \\
\text { Putlitz et al. (2005), Tomaschek et al. } \\
\text { (2003) }\end{array}$ \\
\hline & $\begin{array}{l}\text { Age range groups } 61-63(n=4) ; \\
83-77(n=15) ; \text { and } 80-77 \\
(n=7)^{6}\end{array}$ & $\begin{array}{l}\text { (b) 88-76 (Zrn U-Pb in meta-plagiogranite); } \\
\text { 80, } 77 \text { and 52 (Zrn U-Pb in meta-gabbro); } \\
\text { 89-75 (Zrn U-Pb in eclogite); 83-54 (Zrn } \\
\text { U-Pb in blueschist); 81-80 (Zrn U-Pb in } \\
\text { glaucophanite); 80-77 (Zrn U-Pb in } \\
\text { Chl-schist); and 79 and } 57 \text { (Zrn U-Pb in } \\
\text { Qtz-Mca-schist) }\end{array}$ & & \\
\hline & $\begin{array}{l}\text { Th/U 0.32-1.54 }(n=15) ; \text { and } \\
0.36-1.07(n=7)^{6}\end{array}$ & $\begin{array}{l}\text { (c) } 50-43 \text { ( } \mathrm{Ph} \mathrm{Ar}-\mathrm{Ar} \text { in eclogite); } 52-42(\mathrm{Ph} \\
\mathrm{Ar}-\mathrm{Ar} \text { in omphacitic metagabbro) and } 49-46 \\
\text { (Rb-Sr in omphacite) }\end{array}$ & $\begin{array}{l}(\boldsymbol{e}) \sim 270-500{ }^{\circ} \mathrm{C} \\
\text { and } \sim 0.8-1.8 \mathrm{GPa}\end{array}$ & \\
\hline
\end{tabular}

(a) Metamorphic peak age; (b) protolith crystallization igneous ages and other metamorphic ages; (c) exhumation age; (d) metamorphic peak PT conditions; (e) jadeitite formation PT conditions. Mineral abbreviation in Table 2.

${ }^{1}$ Data from HP-LT rocks from Marun-Keu complex.

2 Data from eclogite facies rocks from Omi schist.

${ }^{3}$ Metamorphic peak of anatectic tonalitic-trondhjemite within Grt-amphibolite blocks.

${ }^{4}$ Data from Mica-albite rock from the NMM.

${ }^{5}$ Data from eclogite-facies bands and boudins from the Chuacús complex.

${ }^{6}$ Data from omphacitite from Syros Island.

However, not all jadeitites are clearly older than their accompanying metabasites in the hosting mélange. Jadeitite from Sierra del Convento in eastern Cuba is an example: the 108-107 Ma U-Pb zircon formation age and the 106-97 Ma Ar-Ar amphibole exhumation age of garnet-amphibolite and anatectic tonalitic-trondhjemite are almost indistinguishable (Table 3; Cárdenas-Párraga et al., 2012; Lázaro et al., 2009). Another example is the Kampos mélange on Syros Island (Greece) where U-Pb dating of zircons from jadeitite, omphacitite, glaucophanite, chlorite-actinolite rock, eclogite, blueschist, metagrabbro and meta-plagiogranite yield identical $\sim 80 \mathrm{Ma}$ ages, suggesting a regional hydrothermal or metasomatic process within the subduction channel rather than in the overlying wedge (Table 3; Bröcker and Enders 1999; Bröcker and Keasling, 2006; Cheney et al., 2000; Keay, 1998; Tomaschek et al., 2003). Thus, the process of jadeitite formation is permissive of age variation compared to HP-LT blocks.

\subsection{Formation of mica-albite rocks}

Another result from this study is that the range of ages for the mica-rich rocks is essentially equal to those of the NMM jadeitites. Mica-albite rocks typically partially encapsulate jadeitite and were interpreted as texturally later than jadeitite but likewise produced by fluid crystallization, perhaps during exhumation (Harlow, 1994). The question was if later, how much later. These new mica-albite rocks dates show that at least in one case, the timing is essentially coeval with the jadeitite from the same area. Consequently, the formation of mica-albite rocks must happen during or immediately after jadeitite formation. Such a rapid sequence of processes would appear to be mediated, in part, by silica activity in the crystallizing fluid, with the constraint that $P-T$ conditions remain relatively constant; within the stability field of albite (i.e. below the $\mathrm{Jd}+\mathrm{Qtz}=\mathrm{Ab}$ reaction yet above the $\mathrm{Jd}+\mathrm{W}=$ Anl reaction; Harlow, 1994). Jadeitite will form when silica activity is well below unity whereas albite in mica rock will form at a higher silica activity (see the jadeitite formation models of Sorensen et al. (2006) and Harlow et al. (2007)). Jadeitite probably forms concurrently with active serpentinization, which drives down silica activity, and albite would form when the serpentinization is locally less influential on fluid composition.

Alternatively, the jadeite to albite evolution may be unrelated to serpentinization with earlier fluids having a low silica activity but the later fluids, also richer in $\mathrm{K}$ (and Ba), having a higher silica activity. In both cases, the process must be active during subduction and requires a chemical evolution of the altering mantle wedge. Perhaps some dynamic deformation and movement at the mantle wedge boundary is required to open and seal the system from being completely overprinted during subduction so that the older record is actually locally preserved. Only careful fine-scale study will resolve the questions that arise here.

\section{Conclusion}

$\mathrm{U}-\mathrm{Pb}$ dates, textural evidence, and trace element analysis of zircons in jadeitite and mica-albite rocks from the serpentinite mélanges of Guatemala support an interpretation that zircon grew during the precipitation of primary P-type jadeitite from hydrothermal fluids. Precipitation occurred during subduction, tens of 
a
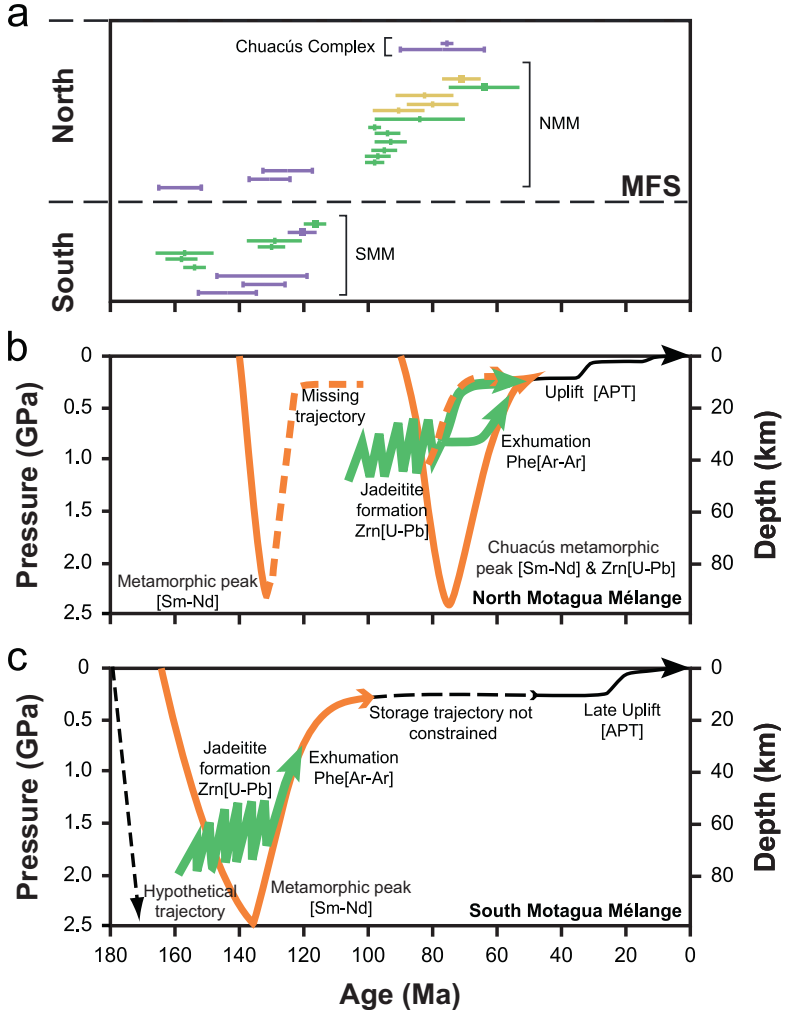

d

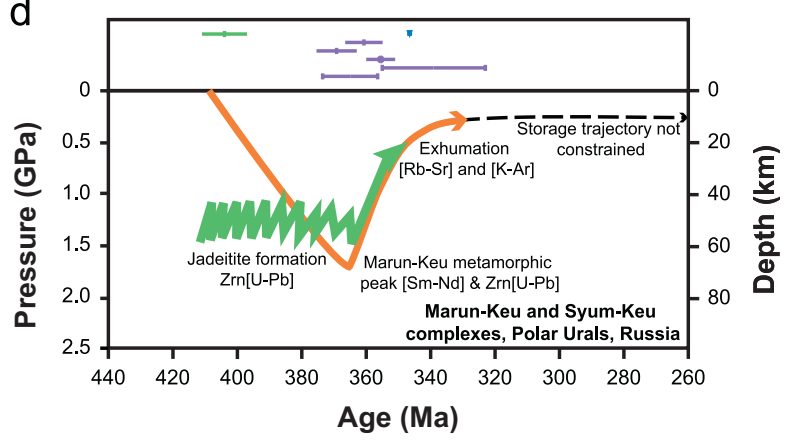

e

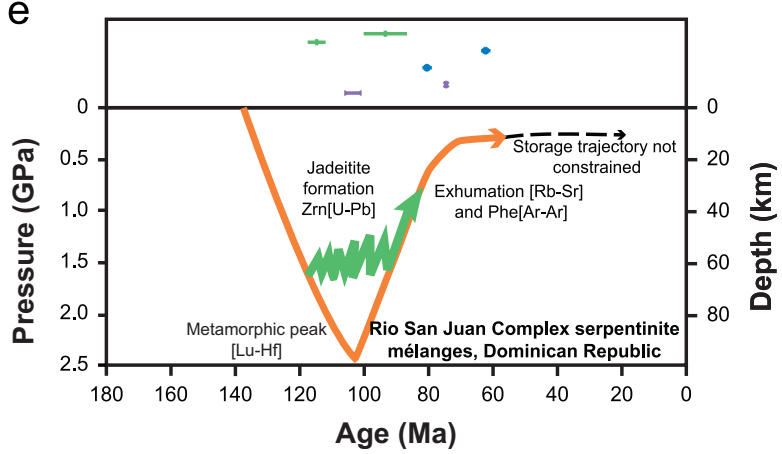

Fig. 6. Pressure-time (Pt) trajectories for P-type jadeitite-bearing serpentinite mélanges and associated HP-LT rocks from the GSZ, the Marun-Keu-Syum-Keu complexes and the Rio San Juan Complex (figure is based on Tsujimori and Harlow (2012)). Thin lines indicate the Pt path for subduction, metamorphism and exhumation of eclogites and blueschist, which is given by the Lu-Hf, Sm-Nd, Rb-Sr, and Ar-Ar. Thick lines show the formation of jadeitites and mica-albite rock during subduction and exhumation; this interpretation is derived from the U-Pb zircon data as well as $\mathrm{Ar}-\mathrm{Ar}$ results on phengite. The zigzag is purely diagrammatic to suggest the residence of these vein rocks in thermally transient storage in the chilled mantle-wedge at the channel margin. Pressure and geochronological data are given in Table 3. Apatite fission track (APT) after Ratschbacher et al. (2009) and Sisson et al. (2007).

millions of years before HP-LT rocks such as eclogites and blueschists recrystallized in the mélange. A series of possible younger dates suggests precipitation may have continued during subduction, and in some cases, during exhumation. Jadeitite crystallization occurred in the mantle wedge above the subduction zone rather than in the subducting slab itself, which presumably continued to subduct into the deeper mantle. These jadeitites are thus samples of upward fluid and mass transfer from the slab during subduction.

\section{Acknowledgments}

This work was partially supported by the Swiss National Science Foundation (SNSF) Prospective researcher's fellowship (PBLAP2-124272) and an AMNH Kathryn W. Davis Postdoctoral fellowship to KEF. We gratefully acknowledge funding from NSF award EAR0309320 and EAR1119403 (GEH) and EAR1119456 (HKB) and the Expedition Fund in the Department of Earth \& Planetary Sciences, AMNH, in support of this research. We would like to thank Martin Grove (Stanford University) and N.A. Zirakparvar (AMNH), for access to the Stanford-USGS SHRIMP-RG facility and help with data interpretation, respectively. The LAMICP-MS analytical work used instrumentation purchased with, and supported by, funding from the ARC, DEST, Macquarie University and industry. We appreciate constructive reviews by H.-P. Schertl and an anonymous reviewer. This contribution is publication \# 876 of the ARC National Key Centre for GEMOC, \# 308 of the ARC
Centre of Excellence for CCFS, and \# 7682 of Lamont-Doherty Earth Observatory.

\section{Appendix A. Supplementary materials}

Supplementary data associated with this article can be found in the online version at http://dx.doi.org/10.1016/j.epsl.2013.04.015.

\section{References}

Authemayou, C., Brocard, G., Teyssier, C., Simon-Labric, T., Gutiérrez, A., Chiquín, E.N., Morán, S., 2011. The Caribbean-North America-Cocos Triple Junction and the dynamics of the Polochic-Motagua fault systems: pull-up and zipper models. Tectonics 30, TC3010, http://dx.doi.org/10.1029/2010TC002814.

Authemayou, C., Brocard, G., Teyssier, C., Suski, B., Cosenza, B., Morán-Ical, S, González-Véliz, C.W., Aguilar-Hengstenberg, M.A., Holliger, K., 2012. Quaternary seismo-tectonic activity of the Polochic Fault, Guatemala. J. Geophys. Res. 117, B07403, http://dx.doi.org/10.1029/2012JB009444.

Belousova, E.A., Griffin, W.L., Shee, S.R., Jackson, S.E., O'Reilly, S.Y., 2001. Two age population of zircons from the Timber Creek kimberlites, Northern Territory, as determined by laser-ablation ICP-MS analysis. Aust. J. Earth Sci. 48, 757-765.

Black, L.P., Gulson, B.L., 1978. The age of the Mud Tank carbonatite, Strangways Range, Northern Territory. BMR J. Aust. Geol. Geophys. 3, 227-232.

Black, L.P., Kamo, S.L., Allen, C.M., Davis, D.W., Aleinikoff, J.N., Valley, J.W., Mundil, R., Campbell, I.H., Korsch, R.J., Williams, I.S., Foudoulis, C., 2004. Improved ${ }^{206} \mathrm{~Pb} /{ }^{238} \mathrm{U}$ microprobe geochronology by the monitoring of a trace-elementrelated matrix effect; SHRIMP, ID-TIMS, ELA-ICP-MS and oxygen isotope documentation for a series of zircon standards. Chem. Geol. 205 (1-2), 115-140.

Bonis, S., Bohnenberger, O., Dengo, G., Mapa geológico de la República de Guatemala. Instituto Geológico Nacional, 1970, 4 map sheets $(1: 500,000)$.

Brocard, G., Teyssier, C., Dunlap, W.J., Authemayou, C., Simon-Labric, T., CacaoChiquín, E.N., Gutiérrez-Orrego, A., Morán-Ical, S., 2011. Reorganization of a 
deeply incised drainage: role of deformation, sedimentation and groundwater flow. Basin Res. 23, 631-651.

Bröcker, M., Enders, M., 1999. U-Pb zircon geochronology of unusual eclogite-facies rocks from Syros and Tinos (Cyclades, Greece). Geol. Mag. 136 (2), 111-118.

Bröcker, M., Enders, M., 2001. Unusual bulk-rock compositions in eclogite-facies rocks from Syros and Tinos (Cyclades, Greece); implications for U-Pb zircon geochronology. Chem. Geol. 175, 581-603.

Bröcker, M., Keasling, A., 2006. Ionprobe U-Pb zircon ages from the high-pressure low-temperature mélange of Syros, Greece: age diversity and the importance of pre-Eocene subduction. J. Metamorphic Geol. 24, 615-631.

Brueckner, H.K., Avé Lallemant, H.G., Sisson, V.B., Harlow, G.E., Hemming, S.R., Martens, U., Tsujimori, T., Sorensen, S.S., 2009. Metamorphic reworking of a high pressure-low temperature mélange along the Motagua fault, Guatemala: record of Neocomian and Maastrichtian transpressional tectonics. Earth Planet. Sci. Lett. 284, 228-235.

Bulle, F., Bröcker, M., Gärtner, C., Keasling, A., 2010. Geochemistry and geochronology of the HP mélanges from Tinos and Andros, cycladic blueschist belt, Greece. Lithos 117, 61-81.

Cárdenas-Párraga, J., García-Casco, A., Harlow, G.E., Blanco-Quintero, I.F., Rojas Agramonte, Y., Kröner, A., 2012. Hydrothermal origin and age of jadeitites from Sierra del Convento Mélange (Eastern Cuba). Eur. J. Mineral. 24, 313-331.

Cheney, J., Schumacher, J., Coath, C.D., Brady, J.B., DiFillipo, E.L., Argyrou, E.N., Otis, J.W., Sable, J.E., Sperry, A.J., Skemer, P.A., 2000. Ion microprobe ages of zircons from blueschists, Syros, Greece. Geol. Soc. Am. Abst. Programs 32A-152

Chiari, M., Dumitrica, P., Marroni, M., Pandolfi, L., Principi, G., 2006. Radiolarian biostratigraphic evidence for a Late Jurassic age of the El Tambor group ophiolites (Guatemala). Ofioliti 31 (2), 141-150.

Dengo, G., 1969. Problems of the tectonic relations between Central America and the Caribbean. Gulf Coast Assoc. Geol. Soc. Trans. 19, 311-320.

Dengo, G., 1985. Mid-America: tectonic setting for the Pacific margin from southern Mexico to northwestern Colombia. In: Nairn, A.E.M., Stehli, F.G., Uyeda, S. (Eds.) The Ocean Basins and Margins: The Pacific Ocean, vol. 7a, Plenum Press, New York, pp. 123-180.

Donnelly, T.W., Horne, G.S., Finch, R.C., 1990. Northern Central America; the Maya and Chortis blocks. In: Dengo, G., Case, J.E. (Eds.), The Geology of North America: The Caribbean Region. GSA Geology of North America H, pp. 37-76.

Faure, M., Monié, P., Fabbri, O., 1988a. Microtectonics and ${ }^{39} \mathrm{Ar}-{ }^{40} \mathrm{Ar}$ dating of high pressure metamorphic rocks of the south Ryukyu Arc and their bearings on the pre-Eocene geodynamic evolution of Eastern Asia. Tectonophysics 156 133-143.

Faure, M., Fabbri, O., Monié, P., 1988b. The Miocene bending of the Southwest Japan: new ${ }^{39} \mathrm{Ar} /{ }^{40} \mathrm{Ar}$ and microtectonic constrains from the Nagasaki schist (western Kyushu), an extension of the Sanbagawa high-pressure belt. Earth Planet. Sci. Lett. 91, 105-116.

Fu, B., Valley, J.W., Kita, N.T., Spicuzza, M.J., Paton, C., Tsujimori, T., Bröcker, M. Harlow, G.E., 2010. Origin of zircons in jadeitite. Contrib. Mineral. Petrol. 159, 769-780.

Fu, B., Paul, B., Cliff, J., Bröeker, M., Bulle, F., 2012. O-Hf isotope constraints on the origin of zircons in high-pressure mélange blocks and associated matrix rocks from Tinos and Syros, Greece. Eur. J. Mineral. 24, 277-287.

García-Casco, A., Rodríguez Vega, A., Cárdenas-Párraga, J., Iturralde-Vinent, M.A., Lázaro, C., Blanco Quintero, I., Rojas Agramonte, Y., Kröner, A., Núñez Cambra, K. Millán, G., Torres-Roldán, R.L., Carrasquilla, S., 2009. A new jadeitite jade locality (Sierra del Convento, Cuba): first report and some petrological and archaeological implications. Contrib. Mineral. Petrol. 158, 1-16.

Geldmacher, J., Martens, U., Hoernle, K., Hauff, F., Boggard, P., Kluegel, A., Geochemical constraints on the pre-Cenozoic subduction history of two margins of the Chortis blocks (northern Central America), Eos Trans AGU 88 (52), 2007, Fal Meet. Suppl., abstract T11D-04.

Glodny, J., Austerhem, H., Molina, J.F., Rusin, A.I, Seward, D., 2003. Rb/Sr record of fluid-rock interaction in eclogites: the Marun-Keu complex, Polar Urals, Russia. Geochim. Cosmochim. Acta 67 (22), 4353-4371.

Glodny, J., Pease, V., Montero, P., Austerheim, H., Rusin, A.I., 2004. Protolith ages of eclogites, Marun-Keu Complex, Polar Urals, Russia: implications for the preand early Uralian evolution of the northeastern European continental margin. In: Gee, D.G., Pease, V. (Eds.), The Neoproterozoic Timanide Orogen of Eastern Baltica, 30. Geological Society London Memoirs, pp. 87-105.

Goffé, B., Rangin, C., Maluski, H., 2002. Jade and associated rocks from the jade Mines area, Northern Myanmar as record of a polyphased high pressure metamorphism. Himalaya-Karakoram-Tibet Workshop meeting (abstracts). J Asian Earth Sci. 20, 16-17.

Griffin, W.L., Powell, W.J., Pearson, N.J., O'Reilly, S.Y., 2008. GLITTER: data reduction software for laser ablation ICP-MS. In: Sylvester, P. (Ed.), Laser Ablation-ICP-MS in the Earth Sciences: Current Practices and Outstanding Issues, 40. Mineralogical Association of Canada, Short Course Series, pp. 307-311.

Grimes, C.B., John, B.E., Keleman, P.B., Mazdab, F.K., Wooden, J.L., Cheadle, M.J., Hanghoj, K., Schwartz, J.J., 2007. Trace element chemistry of zircon from oceanic crust: a method for distinguishing detrital zircon provenance. Geology 35 (7), 643-646.

Harley, S.L., Kelly, N.M., Möller, A., 2007. Zircon behaviour and the thermal histories of mountain chains. Elements 3, 25-30.

Harlow, G.E., 1994. Jadeitites, albitites and related rocks from the Motagua Fault Zone, Guatemala. J. Metamorphic Geol. 12, 49-68.

Harlow, G.E., Sorensen, S.S., 2005. Jade (nephrite and jadeitite) and serpentinite: metasomatic connections. Int. Geol. Rev. 47, 113-146.
Harlow, G.E., Sorensen, S.S., Sisson, V.B., 2007. Jade. In: Groat, L.A. (Ed.), The Geology of Gem Deposits. Short Course Handbook Series 37. Mineralogical Association of Canada, Quebec, pp. 207-254.

Harlow, G.E., Sisson, V.B., Sorensen, S.S., 2011. Jadeitite from Guatemala: new observations and distinctions among multiple occurrences. Geol. Acta 9 (3-4), 363-387.

Harlow, G.E., Hemming, S.R., Avé Lallemant, H.G., Sisson, V.B., Sorensen, S.S., 2004 Two HP/LT serpentine-matrix mélange belts, Motagua Fault Zone, Guatemala: a record of Aptian and Maastrichtian collisions. Geology 32 (1), 17-20.

Harlow, G.E., Sisson, V.B., Tsujimori, T., Sorensen, S.S., Brueckner, H.K., 2008. P-T conditions of eclogite/garnet-amphibolite from serpentinite mélanges along the Motagua fault zone, Guatemala. Geol. Soc. Am. Abst. Programs 40 (6), 452.

Hatten, C.W., Mattison, J.M., Renne, P.R., Somin, M.L., Millán, G., Araqueliants, M.M. Kolesnikov, E.M., Sumin, L.V., Rocas metamórficas de alta presión: nuevos datos acerca de sus edades. Primer Congreso Cubano de Geología, La Habana (Cuba), Memorias, 1989, 118-119.

Itaya, T., Tsujimori, T., Liou, J.G., 2011. Evolution of the Sanbagawa and Shimanto high-pressure belts in SW Japan: insights from $\mathrm{K}-\mathrm{Ar}(\mathrm{Ar}-\mathrm{Ar})$ geochronology. J. Asian Earth Sci. 42, 1075-1090.

Jackson, S.E., Pearson., N.J., Griffin, W.L., Belousova, E.A., 2004. The application of laser ablation inductively coupled plasma-mass spectrometry to in-situ $\mathrm{U}-\mathrm{Pb}$ zircon geochronology. Chem. Geol. 211, 47-69.

Keay, S., 1998. The Geological Evolution of the Cyclades, Greece: Constraints from SHRIMP U-Pb Geochronology. Unpublished Ph.D. Thesis. Australian National University, Canberra, 341 p.

Keppie, J.D., Morán Zenteno, D.J., 2005. Tectonic implications of alternative Cenozoic reconstruction for southern Mexico and the Chortís block. Int. Geol. Rev. 47, 478-491.

Krebs, M., Maresch, W.V., Schertl, G.-P., Münker, C., Baumann, A., Draper, G., Idleman, B., Trapp, E., 2008. The dynamics of intra-oceanic subduction zones: a direct comparison between fossil petrological evidence (Rio San Juan Complex Dominican Republican) and numerical simulation. Lithos 103, 106-137.

Krebs, M., Schertl, H.P., Maresch, W.V., Draper, G., 2011. Mass flow in serpentinitehosted subduction channels: P-T-t path patterns of metamorphic blocks in the Rio San Juan mélange (Dominican Republic). J. Asian Earth Sci. 42, 569-595.

Kunugiza, K., Goto, A., 2010. Juvenile Japan: hydrothermal activity of the HidaGaien belt indicating initiation of subduction of proto-Pacific plate in ca. 520 Ma. J. Geogr. 119 (2), 279-293(in Japanese).

Lagos, M., Scherer, E.E., Tomaschek, F., Münker, C., Keiter, M., Berndt, J., Ballhaus, C., 2007. High precision Lu-Hf geochronology of Eocene eclogite-facies rocks from Syros, Cyclades, Greece. Chem. Geol. 243, 16-35.

Lázaro, C., García-Casco, A., Rojas-Agramonte, Y., Kröner, A., Neubauer, F., IturraldeVinent, M., 2009. Fifty-five-million year history of oceanic subduction and exhumation at the northern edge of the Caribbean plate (Sierra del Convento mélange, Cuba). J. Metamorphic Geol. 27, 19-40.

Leroy, S., Mauffret, A., Patriat, P., Mercier de Lépinay, B., 2000. An alternative interpretation of the Cayman trough evolution from a reidentification of magnetic anomalies. Geophys. J. Int. 141 (3), 539-557.

Ludwig, K.R., Squid 1.02: a user's manual. Berkeley Geochronology Center Special Publication 2, 2001, $19 \mathrm{pp}$

Ludwig, K.R., User's manual for Isoplot 3.00: a geochronological toolkit for Microsoft Excel. Berkeley Geochronology Center Special Publication 4, 2003, 70 pp.

Martens, U.C., Brueckner, H.K., Mattinson, C.G., Liou, J.G., Wooden, J.L., 2012. Timing of eclogite-facies metamorphism of the Chuacús complex, Central Guatemala: record of Late Cretaceous continental subduction of North America's sialic basement. Lithos 146-147, 1-10.

Mattinson, C.G., Wooden, J.L., Liou, J.G., Bird, D.K., Wu, C.L., 2006. Age and duration of eclogite-facies metamorphism, North Qaidam HP/UHP Terrane, Western China. Am. J. Sci. 306, 683-711.

McDonough, W.F., Sun, S., 1995. The composition of the Earth. Chem. Geol. 120 223-254.

Meng, F., Makeyev, A.B., Yang, J., 2011. Zircon U-Pb dating of jadeitite from the Syum-Keu ultramafic complex, Polar Urals, Russia: constraints for subduction initiation. J. Asian Earth Sci. 42, 596-606.

Molina, J.F., Austerhem, H., Glodny, J., Rusin, A., 2002. The eclogites of the Marun-Keu complex, Polar Urals (Russia): fluid control on reaction kinetics and metasomatism during high $\mathrm{P}$ metamorphism. Lithos 61, 55-78.

Mori, Y., Miyamoto, T., Gouzu, C., Shigeno, M., Nishiyama, T., Hyodo, H., 2006 ${ }^{40} \mathrm{Ar}-{ }^{39} \mathrm{Ar}$ and $\mathrm{Rb}-\mathrm{Sr}$ ages of jadeitite from the Nishisonogi metamorphic rocks, Kyushu, Japan (abs.). JpGU Meeting, G122-P009.

Mori, Y., Nishiyama, T., Yanagi, T., 2007. Chemical mass balance in a reaction zone between serpentinite and metapelites in the Nishisonogi metamorphic rocks, Kyushu, Japan: implications for devolatilization. Island Arc 16, 28-39.

Mori, Y., Orihashi, Y., Miyamoto, T., Shimada, K., Shigeno, M., Nishiyama, T., 2011. Origin of zircon in jadeitite from the Nishisonogi metamorphic rocks, Kyushu, Japan. J. Metamorphic Geol. 29, 673-684.

Oberhänsli, R., Bousquet, R., Moinzadeh, H., Moazzen, M., Arvin, M., 2007. The field of stability of blue jadeite: a new occurrence of jadeitite from Sorkhan, Iran, as a case study. Can. Mineral. 45, 1501-1509.

Okrusch, M., Bröcker, M., 1990. Eclogite facies rocks in the Cycladic blueschist belt, Greece: a review. Eur. J. Mineral. 2, 451-478.

Ortega-Gutierrez, F., Solari, L.A., Solé-Viñas, J., Martens, U., Gómez-Tuena, A Morán-Icál, S., Reyes-Salas, M., Ortega-Obregon, C., 2004. Polyphase, hightemperature eclogite-facies metamorphism in the Chuacús complex, central 
Guatemala: petrology, geochronology and tectonic implications. Int. Geol. Rev. $46,445-470$.

Ortega-Gutierrez, F., Solari, L.A., Ortega-Obregon, C., Elías-Herrera, M., Martens, U., Morán-Icál, S., Chiquín, M., Keppie, J.D., Torres de León, R., Schaaf, P., 2007. The Maya-Chortís boundary: a tectonostratigraphic approach. Int. Geol. Rev. 49, 996-1024.

Ortega-Obregón, C., Solari, L.A., Keppie, J.D., Ortega-Gutiérrez, F., Solé, J., Morán-Ical, S., 2008. Middle-Late Ordovician magmatism and Late Cretaceous collision in the southern Maya block, Rabinal-Salamá area, central Guatemala: implications for North America-Caribbean plate tectonics. Geol. Soc. Am. Bull. 120, 556-570.

Pindell, J.L., Kennan, L., Maresch, W.V., Stanek, K.-P., Draper, G., Higgs, R., 2005. Plate-kinematics and crustal dynamics of circum-Caribbean arc-continental interactions: tectonic controls on basin development in Proto-Caribbean margins. In: Avé Lallemant, H.G., Sisson, V.B. (Eds.), Caribbean-South American Plate Interactions, 394. Geological Society of America Special Paper, Venezuela, pp. 7-51.

Putlitz, P., Cosca, M.A., Schumacher, J.C., 2005. Prograde mica ${ }^{40} \mathrm{Ar} /{ }^{39} \mathrm{Ar}$ growth ages recorded in high pressure rocks (Syros, Cyclades, Greece). Chem. Geol. 214, 79-98.

Qiu, Z.L., Wu, F.Y., Yang, S.F., Zhu, M., Sun, J.F., Yang, P., 2009. Age and genesis of the Myanmar jadeite: constraints from $\mathrm{U}-\mathrm{Pb}$ ages and $\mathrm{Hf}$ isotopes of zircon inclusions. Chin. Sci. Bull. 54 (4), 658-668.

Ratschbacher, L., Franz, L., Min, M., Bachmann, R., Martens, U., Stanek, K., Stübner, K., Nelson, B.K., Herrman, U., Weber, B., López-Martínez, M., Jonckheere, R., Sperner, B., Tichomirowa, M., McWillians, M.O., Gordon, M., Meschede, M., Bock, P., 2009. The North American-Caribbean Plate boundary in MexicoGuatemala-Honduras. In: James, K.H., Lorente, M.A., Pindell, J.L. (Eds.), The Origin and Evolution of the Caribbean Plate, 328. Geological Society Special Publication, pp. 219-293.

Rosencrantz, E., Ross, M.I., Sclater, J.G., 1988. Age and spreading history of the Cayman trough as determined from depth, heat flow and magnetic anomalies. J. Geophys. Res. 93 (B3), 2141-2157.

Rubatto, D., 2002. Zircon trace element geochemistry: portitioning with garnet and the link between U-Pb ages and metamorphism. Chem. Geol. 184, 123-138.

Sapper, K., 1905. Über Gebirgsbau und Boden de südlichen Mittelamerikas. Peterm. Mitt. Erg.-H. 151, VI+85.

Sañudo-Wilhelmy, S.A., Flegal, R., 1994. Temporal variation in lead concentrations and isotopic composition in the Southern California Bright. Geochim. Cosmochim. Acta 58 (15), 3315-3320.

Schertl, H.-P., Maresch, W.V., Stanek, K.P., Hertwig, A., Krebs, M., Baese, R., Sergeev, S.S., 2012. New occurrences of jadeitite, jadeite quartzite and jadeite-lawsonite quartzite in the Dominican Republic, Hispaniola: petrological and geochronological overview. Eur. J. Mineral. 24, 199-216.

Shatsky, V.S., Simonov, V.A., Jagoutz, E., Koz'menko, O.A., Kurenkov, S.A., 2000. New data on the age of eclogites of the Polar Urals. Dokl. Earth Sci. 371A, 534-538(in Russian).

Shi, G.H., Cui, W.Y., Liou, J., 2001. The petrology of jadeite-bearing serpentinized peridotite and its country rocks from Northwestern Myanmar (Burma). Acta Petrol. Sin. 17, 483-490.

Shi, G.H., Cui, W.Y., Tropper, P., Wang, C.Q., Shu, G.M., Yu, H.X., 2003. The petrology of a complex sodic and sodic-calcic amphibole association and its implications for the metasomatic processes in the jadeitite area in northwestern Myanmar, formerly Burma. Contrib. Mineral. Petrol. 145, 355-376.

Shi, G.H., Cui, W.Y., Cao, S.M., Jiang, N., Jian, P., Liu, D.Y., Miao, L.C., Chu, B.B., 2008. Ion microprobe zircon $\mathrm{U}-\mathrm{Pb}$ age and geochemistry of the Myanmar jadeitite. J. Geol. Soc. London 165, 221-234.

Shi, G.H., Jiang, N., Liu, Y., Wang, X., Zhang, Z.Y., Xu, Y.J., 2009. Zircon Hf isotope signature of the depleted mantle in the Myanmar jadeitite: implications for mesozoic intra-oceanic subduction between the eastern Indian plate and the Burmese platelet. Lithos 112, 342-350.

Shigeno, M., Mori, Y., Nishiyama, T., 2005. Reaction microtextures in jadeitites from the Nishisonogi metamorphic rocks, Kyushu, Japan. J. Mineral. Petrol. 100, 237-246.

Sisson, V.B., Avé Lallemant, H., Harlow, G.E., Roden-Tice, M., Brueckner, H.K., Hemming, S., Valencia, V., Francis, A., 2007. Geochronologic constraints on the exhumation of the Chortís and Maya blocks, central Guatemala. Geol. Soc. Am. Abst. Programs 39 (6), 237.

Solari, L.A., Ortega-Gutiérrez, F., Elías-Herrera, M., Schaaf, P., Norman, M., Torres De León, R., Ortega-Obregón, C., Chiquin, M., Morán-Ical, S., 2009. U-Pb zircon geochronology of Paleozoic units in Western and Central Guatemala: insights into the tectonic evolution of Middle America. In: James, K.H., Lorente, M.A., Pindell, J. (Eds.), Origin and Evolution of the Caribbean Plate, 328. Geological Society Special Publication, pp. 293-311.
Solari, L.A., Gómez-Tuena, A., Ortega-Gutiérrez, Ortega-Obregón, C., 2011. The Chuacús metamorphic complex, central Guatemala: geochronology and geochemical constraints on its Paleozoic-Mesozoic evolution. Geol. Acta 9 (3-4), 329-350.

Somin, M.L., Millán, G., 1981. Geology of Metamorphic Complexes of Cuba. Nauka Press, Moscow (in Russian).

Somin, M.L., Arakelyants, M.M., Kolesnikov, E.M., 1992. Age and tectononic significance of high-pressure metamorphic rocks of Cuba. Int. Geol. Rev. 34 (2), 105-118.

Sorensen, S., Harlow, G.E., Rumble, D., 2006. The origin of jadeitite-forming subduction zone fluids: CL-guided SIMS oxygen isotope and trace element evidence. Am. Mineral. 91, 979-996.

Tera, F., Wasserburg, G.J., 1972. U-Th-Pb systematics in three Apollo 14 basalts and problem of initial $\mathrm{Pb}$ in lunar rocks. Earth Planet. Sci. Lett. 14, 281-304.

Tomaschek, F., Kennedy, A.K., Villa, I.M., Lagos, M., Ballhaus, C., 2003. Zircons from Syros, Cyclades, Greece-recrystallization and mobilization of zircon during high-pressure metamorphism. J. Petrol. 44 (11), 1977-2002.

Tsujimori, T., 2002. Prograde and retrograde P-T paths of the late Paleozoic glaucophane eclogite from the Renge metamorphic belt, Hida Mountains, southwestern Japan. Int. Geol. Rev. 44, 797-818.

Tsujimori, T., Harlow, G.E., 2012. Petrogenetic relantionships between jadeitite and associated high-pressure and low-temperature metamorphic rocks in worldwide jadeitite localities: a review. Eur. J. Mineral. 24, 371-390.

Tsujimori, T., Itaya, T., 1999. Blueschist-facies metamorphism during Paleozoic orogeny in southwestern Japan: phengite $\mathrm{K}-\mathrm{Ar}$ ages of blueschist-facies tectonic blocks in a serpentinite mélange beneath early Paleozoic Oeyama ophiolite. Island Arc 8, 190-205.

Tsujimori, T., Liou, J.G., 2004. Eclogite-facies mineral inclusions in clinozoisite from Paleozoic blueschist, central Chugoku Mountains, southwest Japan: evidence of regional eclogite-facies metamorphism. Int. Geol. Rev. 46, 215-232.

Tsujimori, T., Matsumoto, K., 2006. P-T pseudosection of a glaucophane-epidote eclogite from Omi serpentinite melange, SW Japan: a preliminary report. J. Geol. Soc. Jpn. 112 (6), 407-414 (in Japanese).

Tsujimori, T., Hyoudo, H., Itaya, T., 2001. ${ }^{40} \mathrm{Ar} /{ }^{39} \mathrm{Ar}$ phengite age constrains on the exhumation of the eclogite facies rocks in the Renge metamorphic belt, SW Japan (abs.). 2001 Japan Earth Planetary Sciences Joint Meeting. Tokyo, Japan.

Tsujimori, T., Liou, J.G., Coleman, R.G., 2004. Comparison of two contrasting eclogites from the Motagua fault zone, Guatemala: southern lawsonite eclogite versus northern zoisite eclogite. Geol. Soc. Am. Abst. Program 36 (5), 136.

Tsujimori, T., Liou, J.G., Wooden, J., Miyamoto, T., 2005. U-Pb dating of large zircons in low-temperature jadeitite from the Osayama serpentinite mélange, SW Japan: insights into the timing of serpentinization. Int. Geol. Rev. 47, 1048-1057.

Tsujimori, T., Sisson, V.B., Liou, J.G., Harlow, G.E., Sorensen, S.S., 2006a. Petrologic characterization of Guatemalan lawsonite eclogite: eclogitization of subducted oceanic crust in a cold subduction zone. In: Hacker, B.R., McClelland, W.C., Liou, J.G. (Eds.), Ultrahigh-Pressure Metamorphism: Deep Continental Subduction, 403. Geological Society of America Special Paper, pp. 147-168.

Tsujimori, T., Sisson, V.B., Liou, J.G., Harlow, G.E., Sorensen, S.S., 2006b. Very lowtemperature record in subduction process: a review of worldwide lawsonite eclogites. Lithos 92 (3-4), 609-624.

Udovkina, N.G., 1985. Eclogites of the SSSR. Nauka Press, Moscow285(in Russian).

Wiedenbeck, M., Alle, P., Corfu, F., Griffin, W.L., Meier, M., Oberli, F., Von Quart, A., Roddick, J.C., Spiegel, W., 1995. Three natural zircon standards for U-Th-Pb, Lu-Th, trace element and REE analyses. Geostand. Newsl. 19 (1), 1-23.

Williams, I., 1998. U-Th-Pb geochronology by ion microprobe. In: Mckibben, M.A., Shanks III, W.C., Ridley, W.I. (Eds.), Applications of Microanalytical Techniques to Understanding Mineralizing Processes. Reviews in Economic Geology, 7. Society of Economic Geologists, Inc., Chelsea, MI, pp. 1-35.

Yui, T.-F., Maki, K., Usuki, T., Lan, C.-Y., Martens, U., Wu, C.-M., Wu, T.-W., Liou, J.G., 2010. Genesis of Guatemala jadeitite and related fluid characteristics: insight from zircon. Chem. Geol. 270, 45-55.

Yui, T.-F., Maki, K., Wang, K.L., Lan, C.Y., Usuki, T., Iizuka, Y., Wu, C.M., Wu, T.W., Nishiyama, T., Martens, U., Liou, J.G., Grove, M., 2012. Hf isotope and REE composition of zircon from jadeitite (Tone, Japan and north of the Motagua fault, Guatemala): implications on jadeitite genesis and possible protoliths. Eur. J. Mineral. 24, 263-275.

Yui, T.-F., Fukoyama, M., Iizuka, Y., Wu, C.-M., Wu, T.-W., Liou, J.G., Grove, M., 2013. Is Myanmar jadeitite of Jurassic Age? A result from incompletely recrystallized inherited zircon. Lithos 160-161, 268-282. 